\title{
Mapping sand and clay-filled depressions on a coastal chalk clifftop using gravity and seismic tomography refraction for landslide hazard assessment, in Normandy, France
}

\author{
Jacob T. ${ }^{a, *}$, Samyn K. ${ }^{\mathrm{b}}$, Bitri A. ${ }^{\mathrm{a}}$, Quesnel F. ${ }^{\mathrm{a}, \mathrm{c}}$, Dewez T. ${ }^{\mathrm{a}}$, Pannet P. ${ }^{\mathrm{d}}$, Meire B. ${ }^{\mathrm{e}}$ \\ a BRGM, 3 avenue Claude Guillemin BP36009, Orléans 45060, Cedex 2, France \\ b BRGM, Parc Activités Porte Sud, Rue Pont du Péage - Bâtiment H1, Geispolsheim 67118, France \\ ' $U M R$, 7327, (CNRS-INSU, BRGM-Université d'Orléans), Orléans, France \\ d BRGM, Pôle technologique Henri Farman, 12 rue Clément Ader, Reims 51100, France \\ ${ }^{\mathrm{e}}$ BRGM, 14 Route d'Houppeville, Mont-Saint-Aignan 76130, France
}

\section{A R T I C L E I N F O}

\section{Keywords:}

Gravity survey

Seismic tomography

Landslide

Cliff collapse

Normandy

Declarations of interest: none.

\begin{abstract}
A B S T R A C T
In this study, we present a complete and successful case study where gravity and seismic refraction surveys detect and map previously poorly known sand and clay-filled depressions within the top chalk layers in a costal context, near Dieppe, Normandy, France. This study was commissioned by local authorities after a coastal chalk cliff collapse exposed a sand and clay-filled depression which turned into a $>100,000 \mathrm{~m}^{3}$ landslide. This resulted in a massive clifftop retreat exceeding $40 \mathrm{~m}$, which threatened infrastructure and amenities. For risk and safety assessment, coastal managers commissioned BRGM to (i) determine the depth and extent of the sand and clay-filled depression, and (ii) map the presence of similar cliff-top depressions in a 2-km-long and 400-m-wide band inland of the coast. Both geophysical methods allow the detection and mapping of the sand and clay-filled depressions, which are characterised by a co-localized deepening of the first seismic horizon and a positive gravity anomaly. Seven auger holes confirm the geophysical interpretation, with depth to the top of the chalk $>60 \mathrm{~m}$ in some instances. A map of the depth to the top of chalk is inverted using the gravity residuals.

The successful mapping of the previously poorly-documented sand and clay-filled depressions on the Dieppe clifftop, using both gravity and seismic refraction tomography, was used in part to generate a Coastal Landslide Hazard Zonation map, which is a useful tool for coastal managers who need to make hazard-mitigating decisions.
\end{abstract}

\section{Introduction}

On December 20, 2012, a chalk cliff collapse exposed a previously poorly known sand and clay-filled depression within the chalk's top in South-West Dieppe, France. The collapse triggered a $>100,000 \mathrm{~m}^{3}$ large-scale landslide of sand and clay material. The landslide is still active at the time of writing this paper. A house located on the cliff edge was destroyed in the event, and a locally important coastal road is presently endangered, being located $<10 \mathrm{~m}$ from the landslide edge. This sequence of events led the 2015 edition of the 'Tour de France' to change its course to avoid this road (Clarke, 2015).

Such nested collapse-triggered landslide hazard phenomenon has rarely been documented in regions of chalk cliffs surrounding the English Channel (Duperret et al., 2004) and it does not fall within the chalk cliff collapse classification defined in Mortimore et al. (2004). While understanding and modeling the specific processes involved in the two-step slope failure are beyond the scope of this paper, a first order interpretation of the processes were formulated in a technical report (Pannet et al., 2015). The cliff collapse occurred after a very rainy period. Water level rise in the sand and clay pocket likely led to local hydrostatic pressure rise, acting upon the surrounding chalk. The increased pressure may have triggered the collapse of the seaward chalk buttress, leading to the wastage of the sand and clay material in the exposed pocket.

For risk and safety assessment, the local coastal managers commissioned the BRGM, the French Geological Survey, to (i) determine the extent of the exposed sand and clay-filled depression, and (ii) map the presence of similar depressions within an area almost $2 \mathrm{~km}$ long and $400 \mathrm{~m}$ large from the clifftop landward (Fig. 1b).

Within this scope, geophysical prospecting was carried out on the exposed clifftop. Electrical resistivity and electromagnetic methods, though well suited to imaging sub-surface clay-filled structures (Ahmed

\footnotetext{
* Corresponding author.

E-mail address: t.jacob@brgm.fr (T. Jacob).
} 


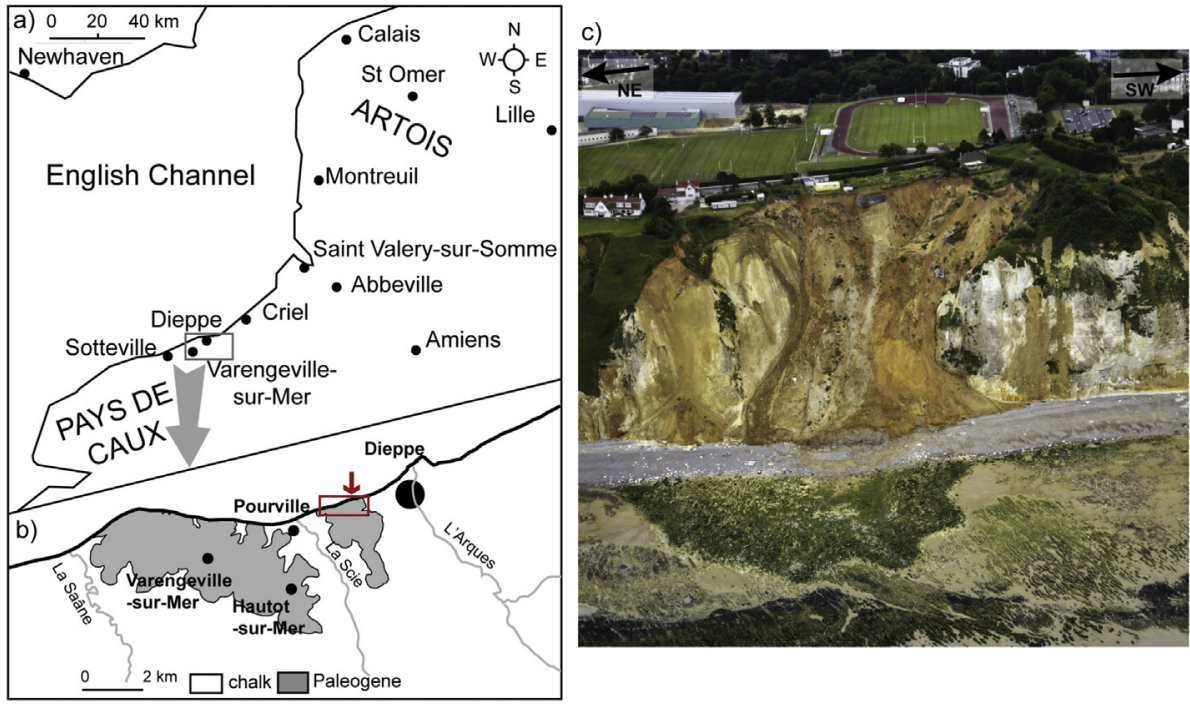

Fig. 1. a) general location map of the study area (grey rectangle) modified after Garel et al. (2013), b) simplified geological map, the red arrow marks the cliff collapse, the red rectangle marks the study area c) photograph of the affected cliff section, taken on 22 July 2013. The sand and clay tongue on the slope is the active landslide. A dark lobe on the platform manifests the presence of the already-removed collapse debris apron. On the plateau, the departmental road from Dieppe to Pourville-sur-Mer, skirted by houses and sports facilities, is threatened by the landslide (Photo Dewez-BRGM). and Carpenter, 2003; Zhou et al., 2000), were not used because of the urbanized context of the cliff-top. Indeed, in urban areas, buried conductive structures such as pipes and cables are detrimental to those methods, as they create noise and artefacts. Consequently, both gravity and seismic refraction methods were carried out. Based on the results of the geophysical prospection, seven auger holes were drilled, five on suspected sand and clay infillings and two for verification.

The present paper describes this case study. We present i) the study area and the geophysical acquisition and processing, ii) the results from the gravity and seismic prospections, with an emphasis on joint interpretation between the two methods, iii) auger hole results, iv) a map of the depth of the chalk's top inverted from gravity data, wherein the sediment-filled depressions within the chalk's top are highlighted. Lastly, we discuss our results from a geophysical standpoint and give a first-order geological interpretation. The outcome of the study, in terms of hazard assessment and of measures taken to mitigate the danger, is finally presented.

\section{Material and methods}

\subsection{Site description}

The cliff collapse is located less than two kilometres to the SouthWest of Dieppe's city centre (Fig. 1a and b), located along the "Alabaster" coast of France. It occurred on December 20th, 2012, and is thought to have mobilized some 20,000 to $30,000 \mathrm{~m}^{3}$ of chalk (Pannet et al., 2015). Sand and clay material, located in a depression within the chalk behind the rupture, was exposed by the rock fall and began flowing, creating a large-scale landslide (Fig. 1c). The landslide has mobilized a volume larger than $100,000 \mathrm{~m}^{3}$, associated to a clifftop retreat $>40 \mathrm{~m}$ (Pannet et al., 2015). It is still active at the time of writing this article.

On site, the chalk cliff is some 45 to $60 \mathrm{~m}$ high and consists of subhorizontally bedded Upper Cretaceous chalk of the Santonian, known as the Seaford Chalk (Mortimore et al., 2004). On top of the chalk, Paleogene Formations of the Thanetian to Ypresian are locally present (Bignot, 1971; Dupuis and Steurbaut, 1987; Dupuis et al., 1998; Garel et al., 2013), which consist mostly of sandy and clayey lithological units, containing a few lignitic or shelly beds. These Formations are some 10 to $45 \mathrm{~m}$ thick in the study area, much thicker in the Varengeville region than in Dieppe area (Fig. 1a). The material exposed within the landslide, which filled a previously poorly known depression within the chalk's top, is lithologically distinct from the overlying Paleogene Formations (see section 2.4). Plio-Quaternary and Quaternary surficial deposits have a highly variable thickness and widely cover the Paleogene Formations and chalk inland. In the following, we refer to the "sand and clay units", not only as the Paleogene Formations overlying the Seaford Chalk and buried below the surficial deposits, but also as the depression sandy and clayey infillings. From a geophysical standpoint indeed, these two units are likely to be indiscernible, having most likely comparable densities and seismic velocities.

\subsection{Gravity data acquisition and processing}

Gravity surveying is a commonly used method to map density contrasts below the surface (Dobrin and Savit, 1960). The successful application of the method is conditioned by the existence of lateral density contrasts below ground. Hence, the density contrast between the chalk and the sand and clay units needs to be large enough to generate gravity anomalies detectable by the gravity method.

Density measurements made at a nearby site on the Seaford Chalk Formation by Duperret et al. (2005) yields a density of $1780 \mathrm{~kg} / \mathrm{m}^{3}$, with a porosity of 0.34 and a degree of saturation of $70 \%$. Due to their heterogeneous nature, assessing the density of sand and clay units is difficult. No density measurements were found in the literature pertaining to them precisely, notably close to or at the surface. Therefore, no prior knowledge existed on the density contrast between the chalk and those sand and clay units.

Within the scope of the present study, some 230 gravity stations were first measured near the landslide in the spring of 2014. The data were processed (see below) and results were deemed conclusive, which lead to the acquisition of a total of 977 gravity stations, measured using a Scintrex CG-5 gravimeter over the survey area (Fig. 2). A calibration factor for that gravimeter, determined over the Orléans-BIPM absolute calibration baseline, spanning $>100 \mathrm{mGals}\left(1 \mathrm{mGal}=10^{-5} \mathrm{~m} / \mathrm{s}^{2}\right)$, was used in data reduction. The calibration coefficient ensures that the gravity differences measured in the field by the meter are accurate. A single base station was used throughout the survey, which was tied to the IGN (Institut Géographique National) absolute gravity network station "Dieppe A".

Stations were spaced $15 \mathrm{~m}$ apart, insofar as terrain access allowed it. Loop duration, the timespan between repeat measurements at the base station to assess instrumental drift, did not exceed $2.5 \mathrm{~h}$. At each station, gravity readings consisted of at least two $60 \mathrm{~s}$ measurements or more if instrument tilt or ambient noise were high. Gravity measurements at 179 stations were repeated in latter loops to determine the reproducibility of the data. The repeat measurements follow a zeromean Gaussian distribution with a standard deviation of $0.012 \mathrm{mGal}$. 


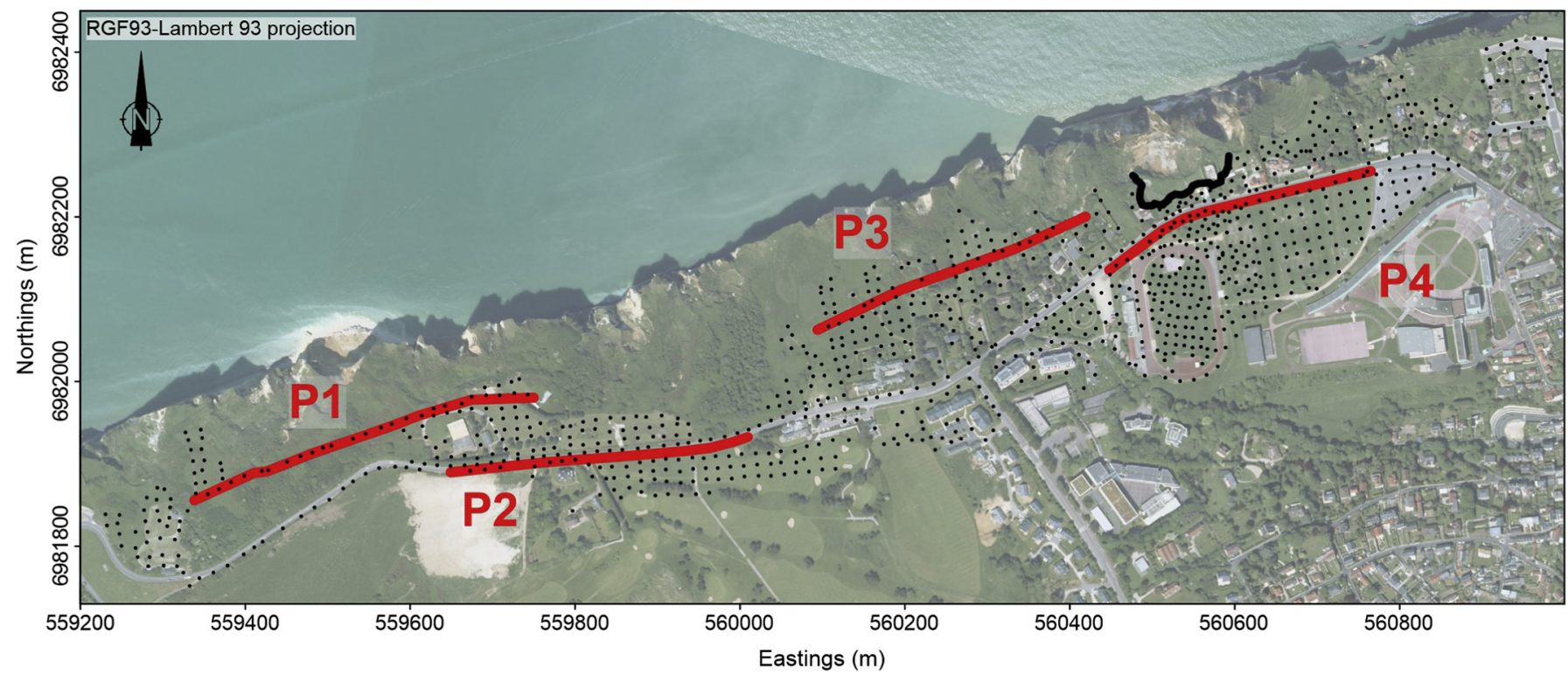

Fig. 2. Location map of the gravity stations (black dots) and the seismic profiles (red lines). The thick black line represents the cliff edge after the collapse; the aerial photograph predates the collapse. (For interpretation of the references to colour in this figure legend, the reader is referred to the web version of this article.)

Station elevation and position were determined using a differential GPS rover (Trimble Geo XH6000 with Zephyr II antenna) post processed against a base station located $<10 \mathrm{~km}$ away from the survey site. GPS repeat measurements were performed along with gravity repeat measurements, and follow a zero mean Gaussian distribution with a standard deviation of $0.02 \mathrm{~m}$ for both horizontal and vertical components.

The data were processed to remove all gravity effects needed to obtain the complete Bouguer anomaly, which reflects the underground density distribution:

- The effects of solid earth tides on gravity were corrected for using the tidal potential from Dehant et al. (1999),

- The effect of tidal ocean loading was corrected for using the FES2004 model (Lyard et al., 2006) using the olfg program (Bos and Scherneck, 2007). Due to the proximity of the survey site with the shoreline, and due to its coarse resolution $(0.6 \mathrm{~km})$ in the olfg program, Bos and Scherneck (2007) recommend that the direct Newtonian effects of the mass redistribution from ocean tides be computed using a higher resolution coastline and precise ocean tide values, in the near field. The Newtonian effects were therefore computed using the Dieppe tide gauge time series and using a $25 \mathrm{~m}$ digital elevation model (DEM) on land to assess the coastline, integrating water mass some $22 \mathrm{~km}$ around the survey site.

- Instrument drift was assumed linear and evaluated using the opening and closing base station measurements of each survey loop,

- The normal gravity value based on the GRS 80 (Moritz, 1980) geodetic system constants using Somigliana's formula was corrected for,

- Free-air and simple Bouguer correction were performed,

- Terrain corrections were computed on land and at sea using nested DEM's of different resolutions, using a prism formulation (Nagy et al., 2000):

OIn the surrounding $100 \mathrm{~m}$ from each station, a $1 \mathrm{~m}$ airborne LIDAR DEM, the RGE Alti ${ }^{\circledR}$ product from IGN was used. The difference between the elevations at the gravity stations obtained by differential GPS and this DEM is $0.01 \pm 0.19 \mathrm{~m}$. This DEM was acquired before the collapse and landslide occurred and so the current topography of the landslide area needed to be updated.

A helicopter-borne photogrammetric flight took place on 16 April
2014, a month before the gravity survey, wherein a set of oblique stereophotographs was captured to reconstruct the topography of the landslide. 3D reconstruction was performed using the method presented in Dewez (2014) and further constrained using the $1 \mathrm{~m} \mathrm{RGE} \mathrm{Alti \circledast}{ }^{\circledR}$ reference DEM. Only the disturbed landslide area was merged within the $1 \mathrm{~m}$ DEM. The photogrammetric DEM was compared with a set of 182 differential GPS positions (see above) and the vertical accuracy was estimated at $-0.05 \pm 0.17 \mathrm{~m}$.

OFrom a distance of $100 \mathrm{~m}$ to $1 \mathrm{~km}$ of each station, a $5 \mathrm{~m}$ DEM down-sampled from the $1 \mathrm{~m}$ hybrid DEM was used.

OFrom $1 \mathrm{~km}$ to $22 \mathrm{~km}$ of each station, a $25 \mathrm{~m}$ DEM from IGN BD ALTI $^{\circledast}$ v1 was used.

OAt sea, ETOPO 1 DEM was used (Amante and Eakins, 2009). Near the coastline, the $25 \mathrm{~m}$ DEM was used to augment the low resolution ETOPO 1 DEM.

Because of the high precision in both gravity and elevation acquisition, the largest error source in the Bouguer anomaly stems from the terrain corrections. The resolution of DEMs used has a direct impact on this error: the higher the DEM resolution, the lower the error, especially in the direct vicinity of the stations (see Schiavone et al. (2009)). In this study, the use of a high resolution $1 \mathrm{~m}$ LIDAR DEM with an accurate landslide topography, thanks to the use of a photogrammetric DEM, greatly reduces the error coming from terrain corrections, although, to our knowledge, there is no straightforward way to determine this error precisely.

To assess the optimal density value used in the computation of the complete Bouguer anomaly, the method proposed by Rao and Murty (1973), based on the method of Parasnis (1952), was used. An optimal density of $1800 \mathrm{~kg} / \mathrm{m}^{3}$ was found, which compares favourably with density measurements made by Duperret et al. (2005) on chalk samples in this area.

A density of $1800 \mathrm{~kg} / \mathrm{m}^{3}$ is therefore used to compute the complete Bouguer anomaly (Fig. 5).

Separation of the Bouguer anomaly into regional and residual components was done by surface fitting using a gridding algorithm provided by D'Errico (2005). Using this algorithm, the regional anomaly (Fig. 6) is evaluated and controlled by a smoothing factor, which was chosen so that the regional anomaly correctly accounts for the long-wavelength components of the Bouguer anomaly, i.e., an EastWest long wavelength gradation, with lower values to the West, and higher values to the East. The regional anomaly accounts for the effects 
of the deep regional geological setting, and not that of the sub-surface, which is highlighted in the residual anomaly.

Subtraction of the regional anomaly (Fig. 6) from the Bouguer anomaly yields the residual anomaly which is representative of the density distribution in the sub-surface (Fig. 7), which will be interpreted in section 2.1 .

\subsection{Seismic data acquisition and processing}

Four P-wave seismic refraction tomography profiles datasets (from P1 profile to P4 profile, Fig. 2) were collected and processed to estimate the sand and clay infillings location and thickness, to characterize the lateral variations of mechanical properties and to evaluate the chalk's top depth, i.e. the thickness of sediment overlying the chalk. The acquisition was performed using two 24 channel Geode (Geometrics) seismographs (48 channels altogether), one 48 channel Stratavizor (Geometrics) seismograph, $10 \mathrm{~Hz}$ vertical geophones with $5 \mathrm{~m}$ geophone spacing, using both a weight drop or an explosive source, with $10 \mathrm{~m}$ source spacing. The main issue for P-wave tomography being the need for a small sampling rate for an accurate first arrival picking, a sampling rate of $0.250 \mathrm{~ms}$, and an acquisition window of $2 \mathrm{~s}$ was chosen. Table 1 summarizes the acquisition geometries and parameters. The elevation of each geophone and seismic source was measured using a differential GPS device with an accuracy of about $10 \mathrm{~cm}$.

Seismic refraction tomography methods typically utilize a grid of either fixed or variable sized cells to represent the subsurface. Forward modeling methods, such as a finite difference method, are used to predict ray paths and travel times between source locations and receivers. Cell P-wave velocities ( Vp) are iteratively adjusted until the misfit between the observed and modeled travel times is within some acceptable range. In this study, the Wavepath Eikonal Traveltime (WET) inversion scheme is used (Schuster and Quintus-Bosz, 1993). The data were processed using the Rayfract commercial software package (Intelligent Resources Inc.). The refraction data were processed by inputting raw field files, defining geometry, and manually picking the first breaks for each shot and each geophone. Fig. 3a and b show examples of the traces produced by the $\mathrm{P}$ wave sources and the related first breaks singled out for the P1 and P2 profiles. The free surface of the model used for the forward calculation in the inversion process includes the topography. Considering the processing of the amplitude spectra on seismic record of the profile P1, the inversion was performed considering a main P-wave arrivals frequency of $25 \mathrm{~Hz}$ (Fig. 3c). All source and receiver locations were used for the refraction tomography. Indepth explanations on the theory and processing for refraction tomography can be found in Sheehan et al. (2005).

The final models were estimated after 40 WET iterations and a good fit (mean RMS error $<2 \%$ ) with the experimental data was obtained (Fig. 4). Considering the ray coverage at the last iteration for all the inverted datasets (not shown), the investigation depth ranged from $65 \mathrm{~m}$ to $80 \mathrm{~m}$ and was therefore adequate to investigate the entire chalk cliff.

\subsection{Auger holes drilling}

Using the results of the gravity and seismic campaigns, seven auger holes were drilled between September 2014 and March 2015 (Fig. 11 and Table 3) with the aim of (i) validating or rejecting the interpretation of the geophysical results, and (ii) assessing the landslide hazard affecting infrastructure near the active landslide or located on geophysical anomalies. The BRGM drill rig consists of a $150 \mathrm{~mm}$ motored auger (a 'Bonne Esperance' rig mounted on a $26 \mathrm{t}$ Iveco), well suited to drilling in unconsolidated sediments up to depths of 50 to $100 \mathrm{~m}$.

\section{Results}

\subsection{Bouguer anomaly and residual anomaly map}

The Bouguer anomaly exhibits an East-West gradient (Fig. 5), with lower values to the East, and higher values to the West, ranging between $-11.969 \mathrm{mGal}$ and $-11.139 \mathrm{mGal}$. A stark East-West gradient is observed at $X=560,500 \mathrm{~m}$. Between $X=560,100 \mathrm{~m}$ and $\mathrm{X}=560,400 \mathrm{~m}$, the isocontour $-11.5 \mathrm{mGal}$ defines boudin-shaped regions of higher values elongated in the $\mathrm{N} 120^{\circ}$ direction.

The regional anomaly is presented in Fig. 6 (see section 1.2 for details), and it accounts for the long wavelengths in the Bouguer anomaly, namely the East-West gradient.

The residual anomaly ranges between $-0.180 \mathrm{mGal}$ and 0.180 mGal (Fig. 7). Its notable features include:

- Positive gravity anomalies, whose magnitudes are typically larger than $0.04 \mathrm{mGal}$, numbered A1 to A19 in Fig. 7. The anomalies are mostly oval-shaped and contiguous, and some form chain-like structures elongated in the North-South direction, such as A2 and $\mathrm{A} 1$, or elongated in the $\mathrm{N} 120^{\circ}$ direction, such as A7, A8, A9 and A10, and $\mathrm{A} 11$ and $\mathrm{A} 12$. Note that $\mathrm{A} 1$ is directly adjacent to the active landslide.

- Negative anomalies between the positive anomalies, the highest magnitude negative anomaly reaching $-0.170 \mathrm{mGal}$, immediately to the East of anomaly A2.

Based on pre-existing auger holes and surface geology, a qualitative interpretation of the gravity anomalies is now assessed. Four auger holes were drilled in the study region (boreholes S1, S5, S6 and S7, see location map on Fig. 7), in the scope of a previous study of the collapse hazard (Masson, 1967). A further borehole, SD1, was drilled in 2013, commissioned by the city of Dieppe. With the exception of auger hole S5, the top of the chalk was reached between 12 and $16.5 \mathrm{~m}$ in all boreholes (Table 2). In hole S5, drilling was stopped at $21 \mathrm{~m}$ depth without reaching the chalk. This auger hole is located within the terrain that slid in December 2013 (Fig. 7). In all holes, sandy and clayey facies lie above the chalk, when reached.

In the field, the landslide rupture surface reveals the presence of clayey and sandy facies for at least thirty to forty meters below the surface (Fig. 1), which explains why borehole S5 has not reached the chalk at $21 \mathrm{~m}$ depth. Furthermore, the crown of the landslide is located directly adjacent to positive anomaly A1 (Fig. 7).

Based on the afore-mentioned observations, our working hypothesis is that the positive gravity anomalies are associated to, and possibly caused by, the thick sand and clay infillings of depressions within the chalk. This would imply that the sand and clay material is denser than

Table 1

Summary of the seismic acquisition geometries and parameters for the different P-wave profiles collected.

\begin{tabular}{|c|c|c|c|c|c|c|c|}
\hline \multicolumn{8}{|c|}{ Seismic acquisition parameters } \\
\hline Seismic profile & Receiver spacing & Source spacing & Number of geophones & Geophone & Type of source & Sampling rate & Time window \\
\hline P1 & $5 \mathrm{~m}$ & $10 \mathrm{~m}$ & 87 & $10 \mathrm{~Hz}$ & $125 \mathrm{~g}$ Explosive & $0.250 \mathrm{~ms}$ & $2 \mathrm{~s}$ \\
\hline P2 & $5 \mathrm{~m}$ & $10 \mathrm{~m}$ & 72 & $10 \mathrm{~Hz}$ & Weight drop & $0.250 \mathrm{~ms}$ & $2 \mathrm{~s}$ \\
\hline P3 & $5 \mathrm{~m}$ & $10 \mathrm{~m}$ & 72 & $10 \mathrm{~Hz}$ & $125 \mathrm{~g}$ Explosive & $0.250 \mathrm{~ms}$ & $2 \mathrm{~s}$ \\
\hline P4 & $5 \mathrm{~m}$ & $10 \mathrm{~m}$ & 70 & $10 \mathrm{~Hz}$ & Weight drop & $0.250 \mathrm{~ms}$ & $2 s$ \\
\hline
\end{tabular}



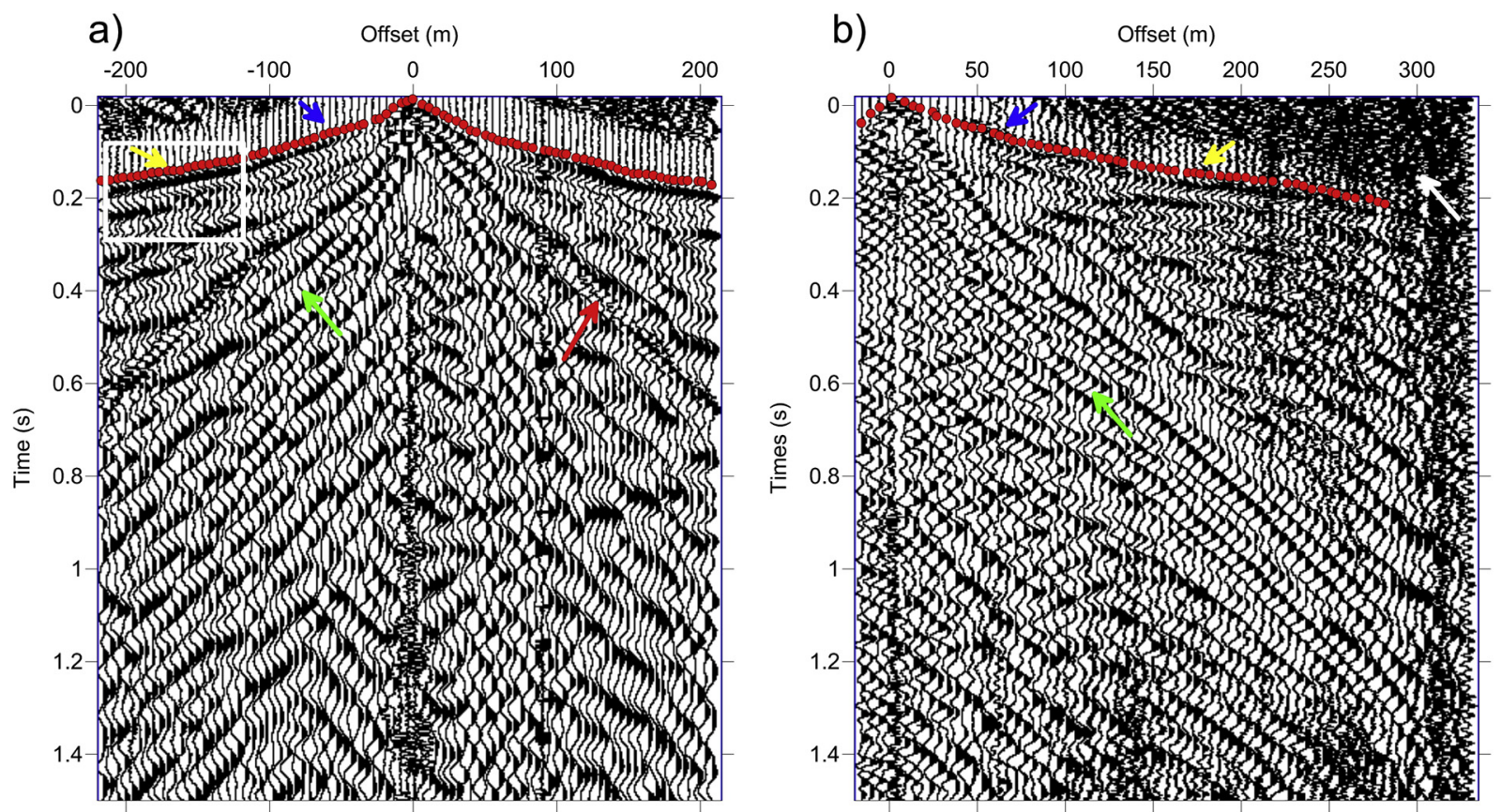

C) Amplitude Spectra

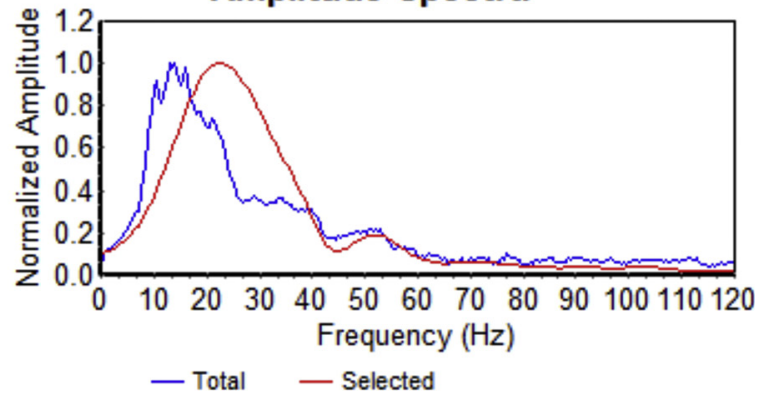

Fig. 3. Examples of seismic records with AGC scaling applied for the a) P1 and b) P2 profiles. Manually picked first breaks appear in red dots. Arrows respectively highlight direct P-wave (blue), refracted P-wave (yellow), surface waves (green), air waves (red) and ambient noise (white). c) Amplitude spectra for the total record shown in a) and for a selection of P-wave arrivals represented by the overlaid white rectangle. (For interpretation of the references to colour in this figure legend, the reader is referred to the web version of this article.)

the chalk.

4. Consequently, negative anomalies can be associated to sand and clay cover of limited thickness

This working hypothesis needs to be corroborated by independent data regarding the chalk's cover thickness, namely seismic refraction data and the newly drilled auger holes.

\subsection{Seismic refraction tomography}

The interpreted Vp models for profiles P1 to P4 are shown in the Figs. 8 and 9. A careful study of all profiles reveals that the P-wave tomography highlights the presence of an average $20 \mathrm{~m}$ thick superficial low Vp $(<1300 \mathrm{~m} / \mathrm{s})$ layer, which locally shows very low Vp values $(<700 \mathrm{~m} / \mathrm{s})$. The known geometry of the cover, consisting of clay and sand deposits, as observed in boreholes S1, S5, S6 and S7 (Fig. 8 and Table 2) in the close vicinity of the profiles P3 and P4, compares favourably with the depth of the $1300 \mathrm{~m} / \mathrm{s} \mathrm{Vp}$ contour. As Vp for sandy-clay deposits range between $400 \mathrm{~m} / \mathrm{s}$ and $1200 \mathrm{~m} / \mathrm{s}$, (Bourbié et al., 1987), we therefore associate this layer with the sand and clay deposits.
A second layer is characterised by intermediate velocities $(1300 \mathrm{~m} /$ $\mathrm{s}<\mathrm{Vp}<2100 \mathrm{~m} / \mathrm{s}$ ), found below this first layer. According to the same borehole characteristics, we interpret this intermediate layer as the chalk bedrock. However, Vp values for unweathered chalk are typically larger than $2100 \mathrm{~m} / \mathrm{s}$ (Bourbié et al., 1987; Senfaute et al., 2005). Therefore, we interpret this layer as weathered chalk.

The $1300 \mathrm{~m} / \mathrm{s} \mathrm{Vp}$ isocontour, which we interpret as the top of the chalk, or the base of the sand and clay units, displays strong variability in altitude. Notably, local depressions are evident in regions marked by black arrows on Fig. 8, reaching elevations of $<50 \mathrm{~m}$, and showing a minimum elevation of $30 \mathrm{~m}$ a.s.l. between abscissa $60-130 \mathrm{~m}$ on profile 4 , near the collapse. Note that superficial very low Vp values $(<700 \mathrm{~m} /$ s) are systematically associated to the above-mentioned local deepening of the $1300 \mathrm{~m} / \mathrm{s} \mathrm{Vp}$ horizon on all profiles, revealing low mechanical properties associated with the depressions.

We interpret these structures as clay and sand infillings of local narrow and deep depressions within the chalk.

The sudden elevation variations of the $1300 \mathrm{~m} / \mathrm{s}$ Vp horizon (especially on profiles P2 and P3) are interpreted as due to discontinuities, because of the sudden shifts between the layers, named D1 to D12 (Figs. 8 and 9). Those discontinuities are localized at the edges of the depressions, suggesting that they likely played a role in their 

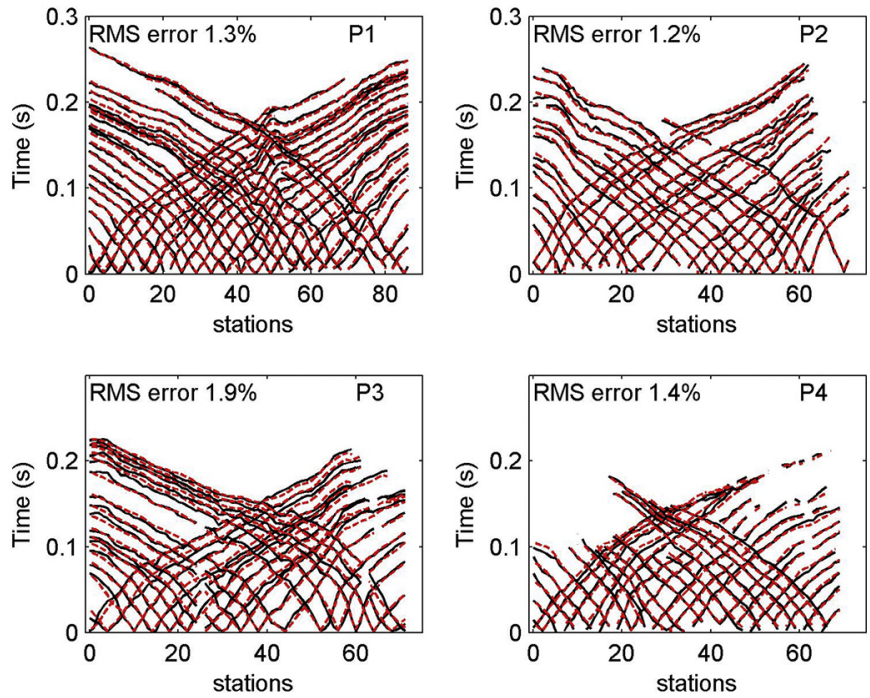

Fig. 4. Comparison between modeled (red dotted lines) and experimental (black solid lines) first-breaks for final Vp models. For clarity, only one out of two sources is shown. (For interpretation of the references to colour in this figure legend, the reader is referred to the web version of this article.)

formation.

The third layer is characterised by high Vp values (Vp $>2100 \mathrm{~m}$ / $\mathrm{s}$ ), and plausibly corresponds to the unweathered chalk. Vp measured in chalk having the same porosity as that of the study area range between 2200 and $2600 \mathrm{~m} / \mathrm{s}$ (Bourbié et al., 1987; Senfaute et al., 2005), thereby validating our choice of $2100 \mathrm{~m} / \mathrm{s}$ as the limit between weathered and unweathered chalk.

The complete profile set is shown with a 3D visualization in Fig. 9, which highlights both the continuity of the $1300 \mathrm{~m} / \mathrm{s}$ horizon between profiles, and the local depressions.

\subsection{Gravity-seismic tomography joint interpretation}

Gravity residuals along seismic profiles are now jointly analysed with respect to the Vp models (Fig. 10). The following noteworthy observations stand out:
- Identified zones where the first seismic layer is locally thick (see section 2.2) are spatially correlated with positive residual gravity anomalies. This is particularly evident when seismic profiles intersect high magnitude positive anomalies at their apex (Fig. 10e). Such is the case along profile P2 with anomaly A14 (Fig. 10b), and along profile P3 with anomaly A10 (Fig. 10c). In those cases, the large positive anomalies are associated with shallow $<700 \mathrm{~m} / \mathrm{s}$ materials within the first $15 \mathrm{~m}$, and a deepening of all other velocity isocontours. Note that although profile $\mathrm{P} 4$ neither crosses anomalies A1 and A2 through their apexes, a significant low-velocity zone is observed below those anomalies (Fig. 10d). This low velocity zone is adjacent to the active landslide.

- Interpreted fault zones (see section 2.2) on the velocity cross-sections are located on the edges of the positive gravity anomalies (Fig. 10e), where the horizontal gravity gradient is important.

- Negative values of the residual anomaly are associated to zones where the first seismic layer, associated to sand and clay deposits, is shallower. This is especially notable within the first $50 \mathrm{~m}$ of profile P4 (Fig. 10d), where the gravity low is associated with a rise in the velocity contour lines.

Based on the afore-mentioned observations, we propose that the positive anomalies in the gravity residuals and the deepening of the first seismic horizon defined by $\mathrm{Vp}<1300 \mathrm{~m} / \mathrm{s}$ are both geophysical signatures, or proxies of, the sand and clay infillings within deep local depressions incised within the top of the chalk.

This implies that the sand and clay material is denser than the chalk while having a lower P-Wave velocity than that of the chalk. Although no direct measurement of the density of the sand and clay units exist in the study region, it is plausible that their density is larger than that of the chalk. Indeed, the density of unconsolidated sand and clay may range between $1700 \mathrm{~kg} / \mathrm{m}^{3}$ and $2200 \mathrm{~kg} / \mathrm{m}^{3}$ with a strong influence of porosity and water saturation (Nettleton, 1971), while the chalk density is $1800 \mathrm{~kg} / \mathrm{m}^{3}$ near the study region (Duperret et al., 2005).

The $\mathrm{Vp}$ in unconsolidated sand and clay facies is typically smaller than $1200 \mathrm{~m} / \mathrm{s}$ (Bourbié et al., 1987), which is smaller than the measured Vp in chalks which range between 2200 and $2600 \mathrm{~m} / \mathrm{s}$ (Bourbié et al., 1987; Senfaute et al., 2005).

\subsection{Newly-drilled auger holes}

We positioned Auger hole FT1 within gravity anomaly A1,

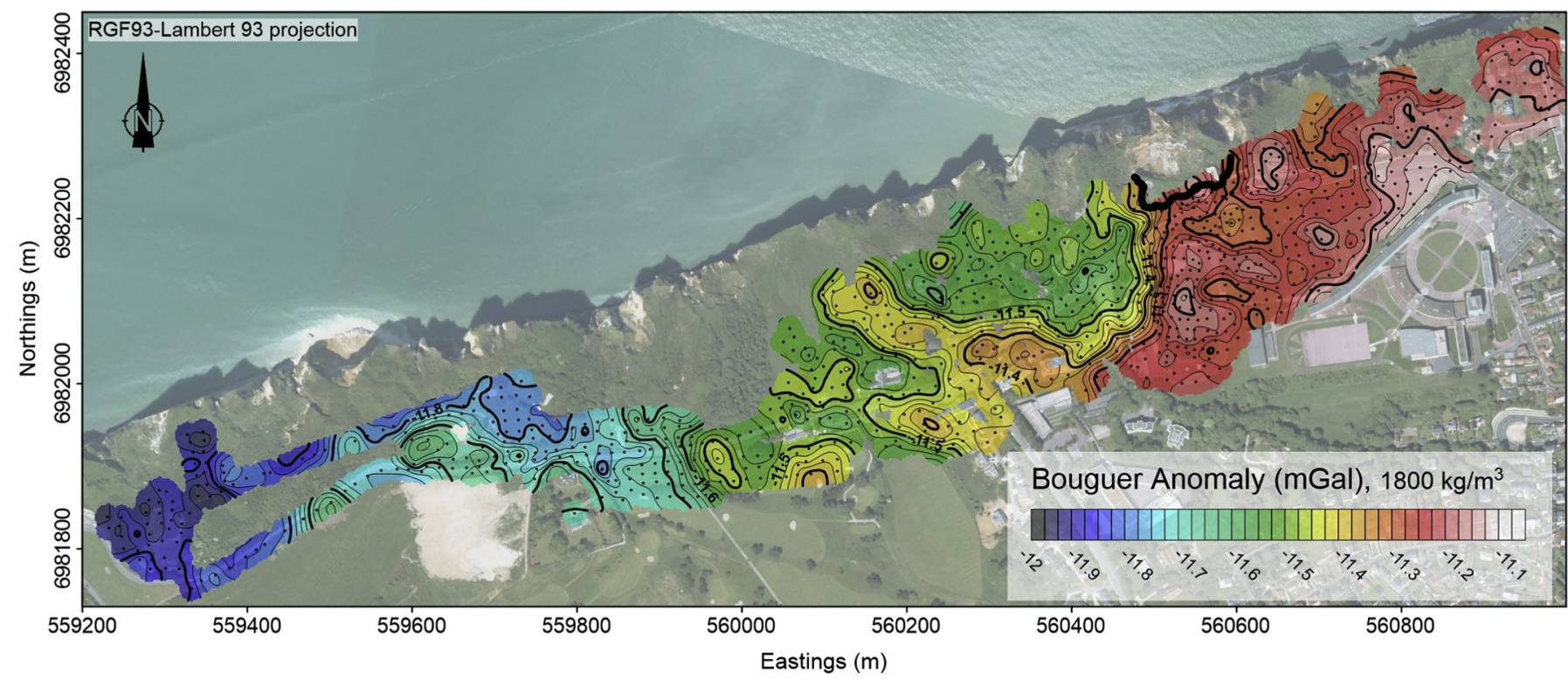

Fig. 5. Bouguer anomaly map for a reduction density of $1800 \mathrm{~kg} / \mathrm{m}^{3}$. The dots represent the stations. The thick black line represents the cliff edge after the collapse. 


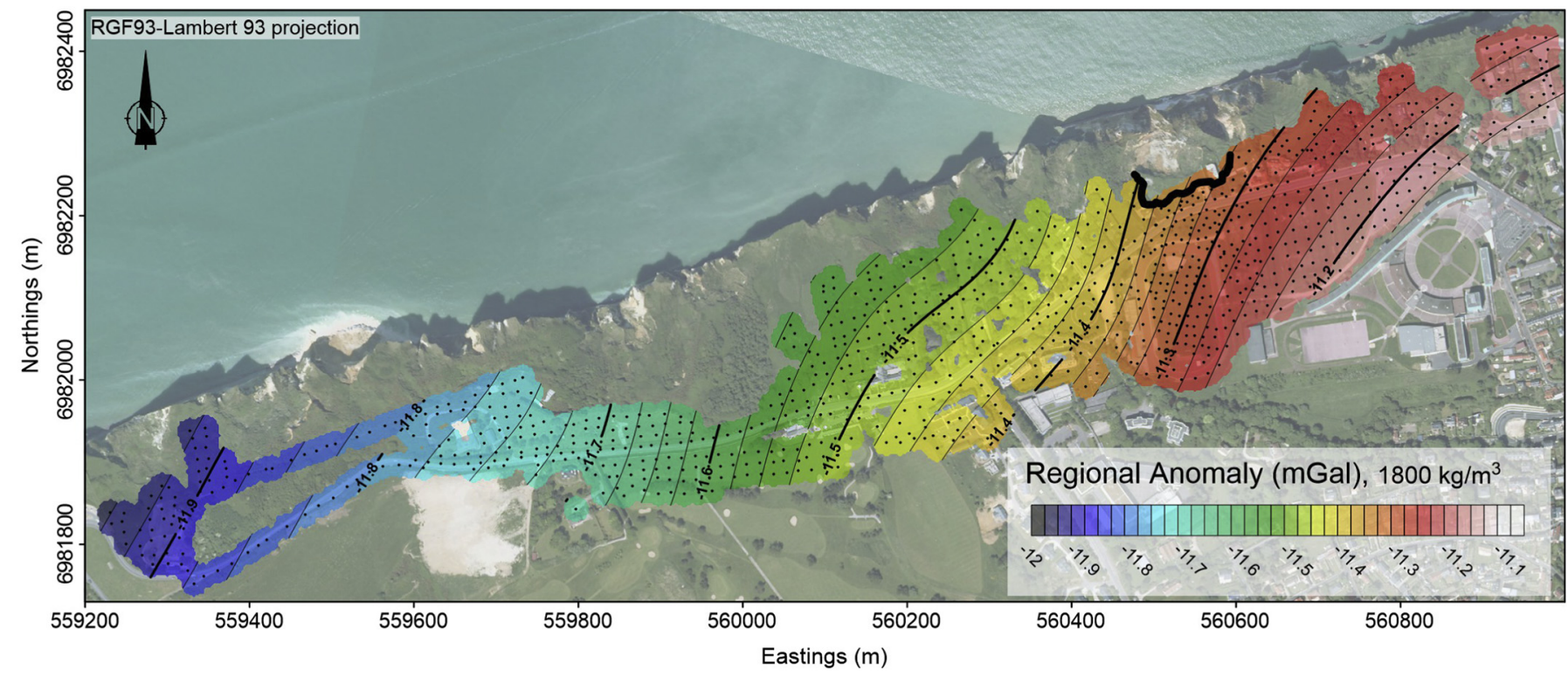

Fig. 6. Regional anomaly map. The dots represent the stations. The thick black line represents the cliff edge after the collapse.

coincident with a seismic low velocity zone, between the crown of the landslide and a major road at risk. The drill bit was stuck at $55 \mathrm{~m}$ depth in a very coarse flint gravel, thus without having reached the top of the chalk. We surmise that the top of the chalk could be a few meters below
$55 \mathrm{~m}$ depth at this location, as the flint gravel may have a Clay-withflints origin, which lies directly above the chalk.

A well $\log$ was made and shows alternating beds of sands, clays, and gravels, organized in seven fining-upwards sequences all exhibiting

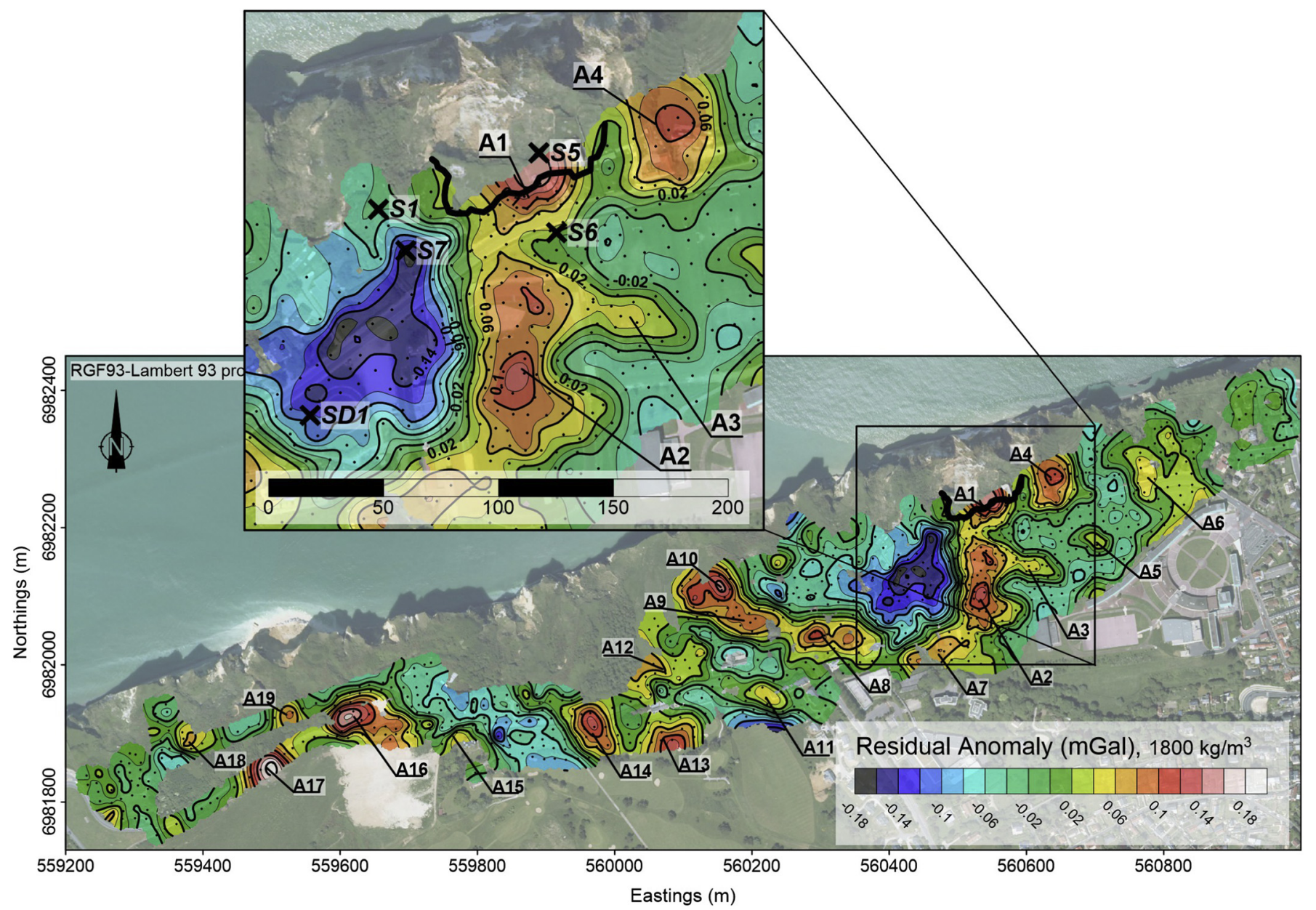

Fig. 7. Residual anomaly map. The dots represent the stations. Positive anomalies are numbered A1 to A19. The thick black line represents the cliff edge after the collapse. The inset shows the location of the pre-existing Auger and boreholes (black crosses). 
Table 2

Pre-existing borehole characteristics.

\begin{tabular}{lll}
\hline Auger/borehole & $\begin{array}{l}\text { Depth to the top of the } \\
\text { Chalk }(\mathrm{m})\end{array}$ & Gravity situation \\
\hline S1 & 15.5 & $-0.035 \mathrm{mGal}$ \\
S5 & $>21 \mathrm{~m}$ & $\begin{array}{l}\text { Outside gravity grid -adjacent to } \\
\text { A1 }\end{array}$ \\
S6 & 12 & $0.028 \mathrm{mGal}$ \\
S7 & 16.5 & $-0.151 \mathrm{mGal}$ \\
SD1 & 16.5 & $-0.123 \mathrm{mGal}$ \\
\hline
\end{tabular}

erosion surfaces at their base. The beds are typically 1 to $5 \mathrm{~m}$ thick. These sequences are very distinct from the known Paleogene Formations deposited on top of the chalk, as described in the geological map of the region (Bignot, 1971) and in publications (e.g. (Dupuis et al., 1998)). Those sequences and their facies can be interpreted as fluvial deposits of probable Pleistocene age, but could be older (Neogene) as well, given the regional geological setting (Dugué et al., 2012; Quesnel, 1997; Quesnel et al., 2003).

Auger hole FT2 is positioned within anomaly A4, in the courtyard of a private house. The top of the chalk was reached at a depth of $58 \mathrm{~m}$. The well log consists again of alternating beds of sands, clays, and gravels, where five fining-upwards sequences are identified, following a slight different pattern than that observed in borehole FT1. As well as in FT1, the sediments do not belong to the Paleogene Formations deposited on top of the chalk, but rather to fluvial deposits of Pleistocene or possibly Neogene age. Interestingly, the contact of the basal coarse gravel bed onto the (rather hard) chalk is irregular and consists of around $2 \mathrm{~m}$ of in situ Quaternary Clay-with-flints (Quesnel, 1997; Quesnel et al., 2003).

Auger hole FT3 was drilled at the apex of anomaly A2, in the middle of a track and field stadium, and reached the top of the chalk at a depth of $63 \mathrm{~m}$ below the surface. The well log consists of alternating beds of sand, clay, and gravels, with five fining-upwards sequences identified, not that much distinct in thickness, colour, and grain size as those identified in FT1 and FT2. Again, these sediments are not the typical Paleogene Formations deposited on top of the chalk, but fluvial deposits of probable Pleistocene or possibly Neogene age.

The top of the chalk is reached at $20 \mathrm{~m}$ depth in auger hole FT4, located in another courtyard of a private house and at the flank of anomaly A4. Three distinct sedimentary sequences are observed, from gravel to clay. The typical Paleogene sand and clay lithounits are distinct from these sequences, which are similar in facies to those crossed by auger holes FT1 to FT3 and can be interpreted also here as fluvial deposits of probable Pleistocene or possibly Neogene age.

Auger hole FT5 is located in a negative gravity anomaly (blue hues in the colormap) immediately to the West of anomaly A2. The top of the chalk is reached just $12 \mathrm{~m}$ below the surface, showing the typical Paleogene Formations, Thanetian and Ypresian in age.

Auger hole FT6, within anomaly A16, reaches the top of the chalk at $27 \mathrm{~m}$ below the surface, and goes through some $15 \mathrm{~m}$ of unidentified sand and clay units, organized in a single fining-upwards sequence, deposited above $9 \mathrm{~m}$ of Paleogene Formations.

Finally, in auger hole FT7, located in a slightly negative anomaly, the depth of the top of the chalk is $19 \mathrm{~m}$ below the surface, and it is overlain by the expected Paleogene Formations (Thanetian and
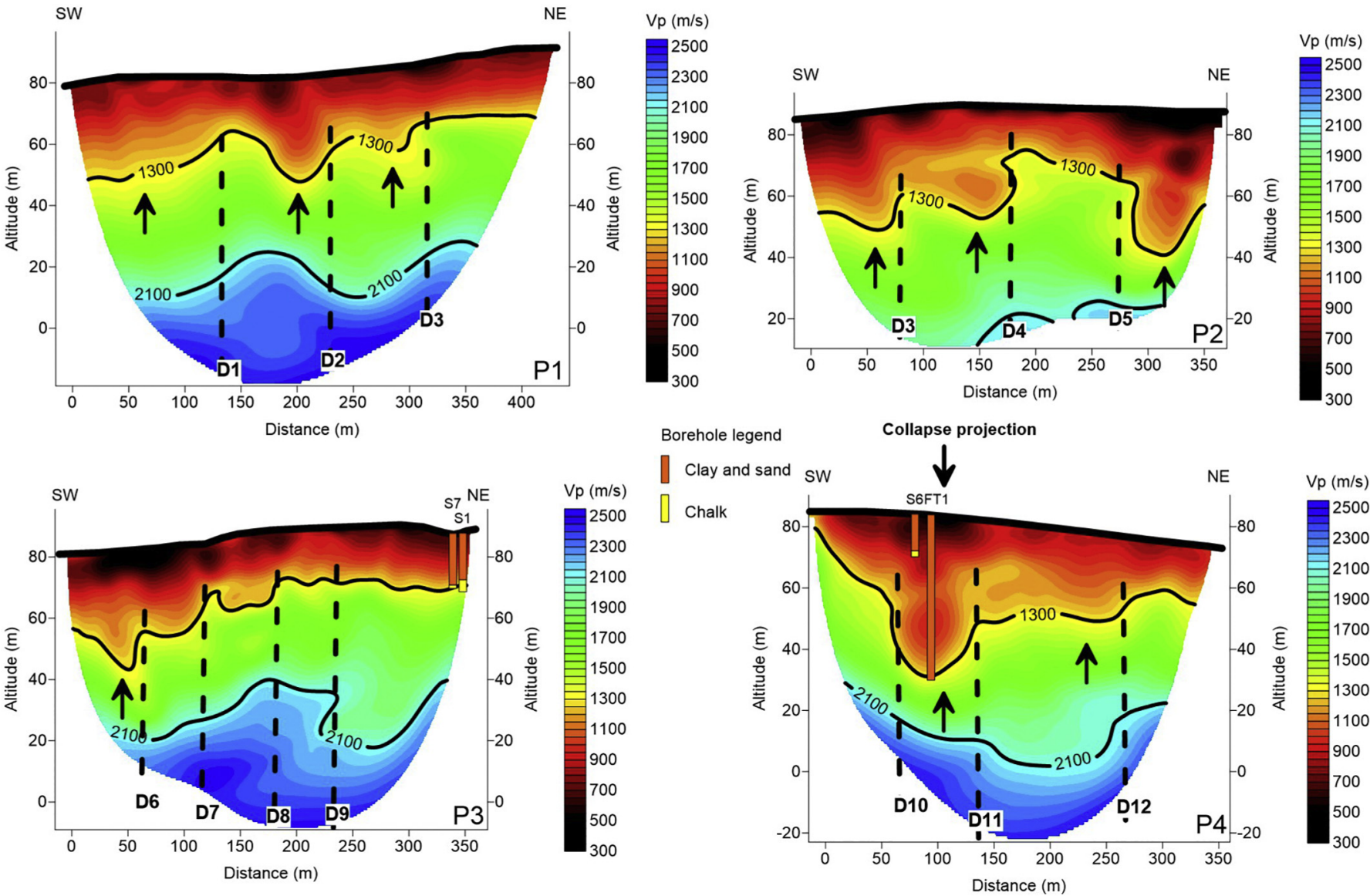

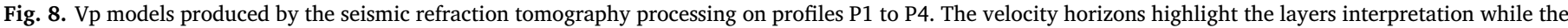

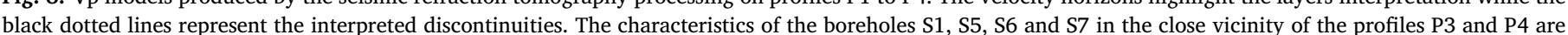

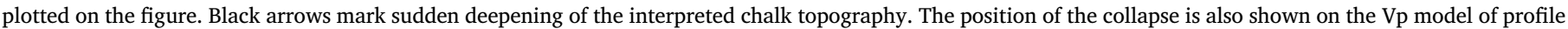
4. 


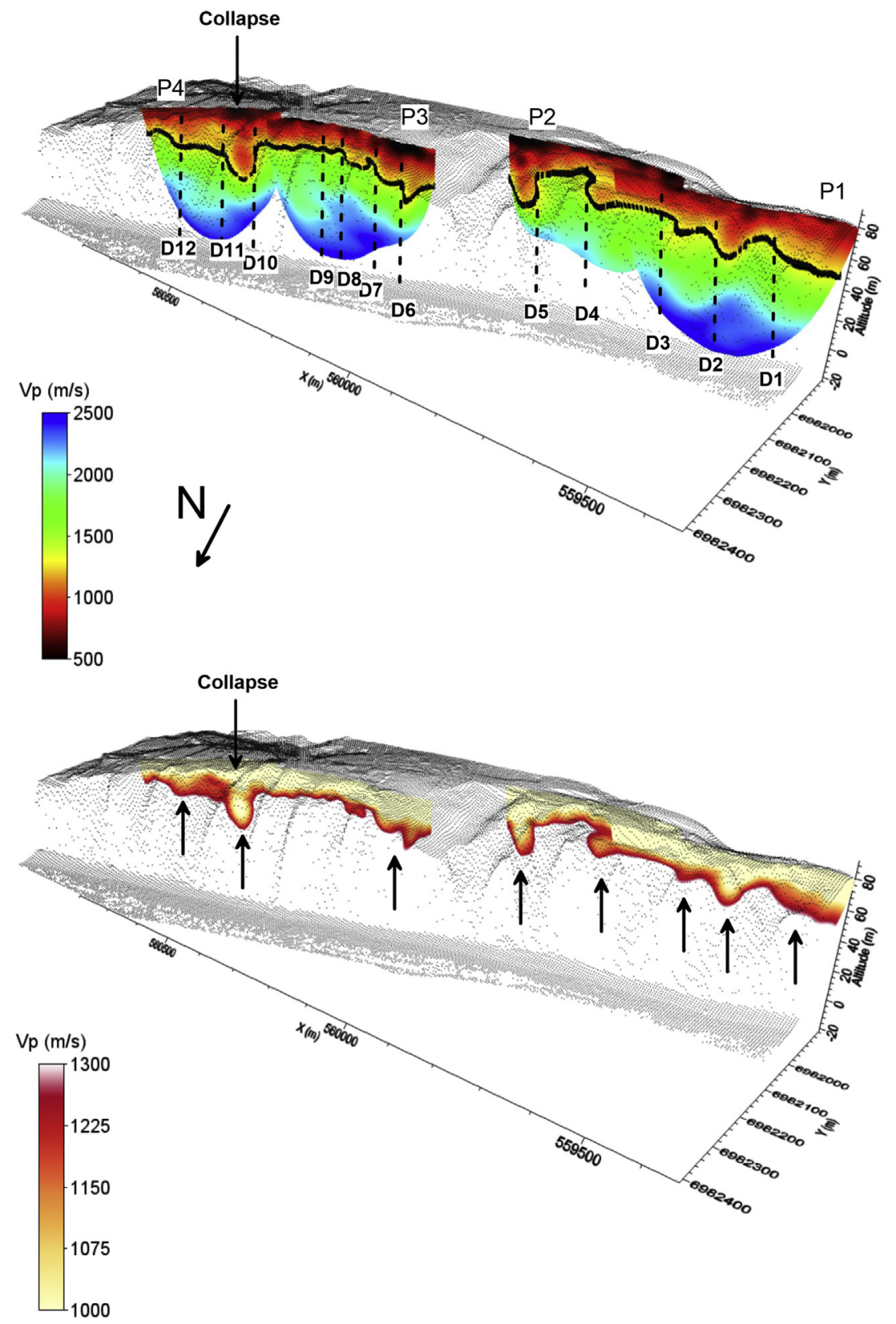

Fig. 9. 3D visualization of the P-wave tomography results with a global colour scale (up) and a colour scale focused on Vp values in the range of the identified low velocity areas. Elevations from the $1 \mathrm{~m}$ LIDAR DEM survey overlay the plot in grey dots. The $1300 \mathrm{~m} / \mathrm{s}$ Vp horizon appears in a black solid line. Interpreted discontinuities D1 to D12 are presented in the upper plot with black dotted lines while the observed depressions are marked on the lower plot with vertical black arrows. The position of the collapse is also shown.

Ypresian) mapped in the area.

To sum up, the new auger holes drilled in positive gravity anomalies systematically encounter important thicknesses $(>20 \mathrm{~m}$, and up to $63 \mathrm{~m}$ ) of sandy, gravelly and clayey sediments, which do not belong to the Paleogene Formations, as potentially expected from the geological map. Instead, they are fluvial deposits, of probable Pleistocene or possibly Neogene age. The auger holes drilled within negative anomalies encounter $<20 \mathrm{~m}$ of the expected Paleogene Formations deposited on top of the chalk (Thanetian and Ypresian).

Therefore, both positive gravity anomalies and the thickening of the first seismic layer are a proxy for the sand, gravel and clay-filled depressions at the top of the chalk formation. Both gravity and seismic methods are hence well suited to delineate the occurrence of the sand and clay-filled depressions on a map and in cross-sections, respectively.

\subsection{Depth of the chalk's top}

For hazard assessment, the depth of the chalk's top, i.e. also the thickness of the cover, is of prime interest. With simplifying assumptions, this depth is inverted from the gravity data. The simplifications made are the following:

- We consider a two-layer model: the top layer representing the sand, clay and gravel unit, the bottom layer representing the chalk. We do not make any distinction in terms of density between the Paleogene Formations and the sand and clay units filling the depressions.

- To each layer is assigned a unique density value, i.e. the density is considered homogeneous and constant within both layers.

To invert for the depth of the chalk, we use an iterative algorithm 
a)
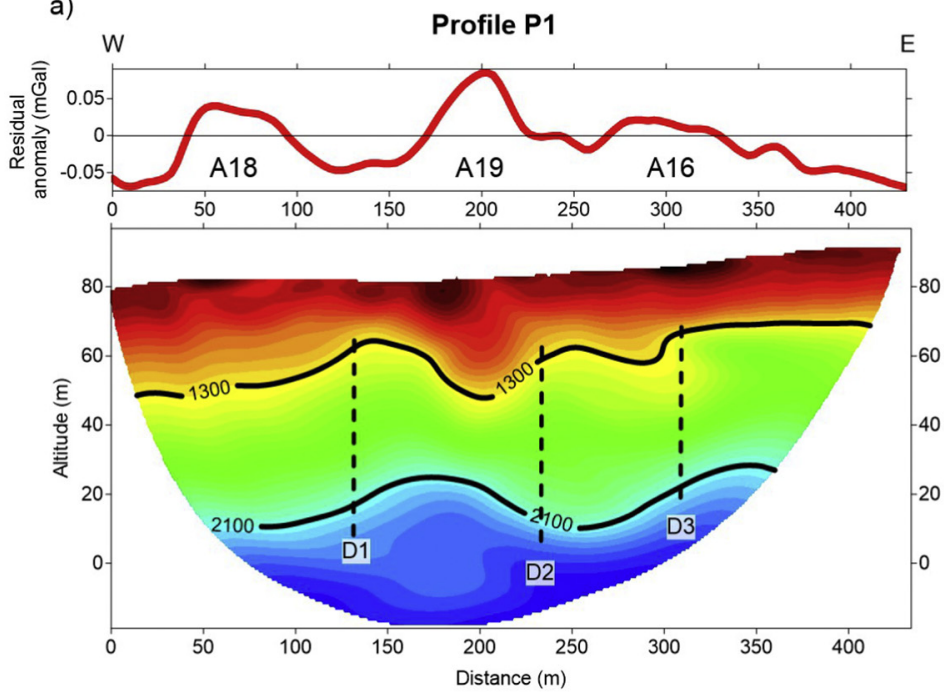

c)
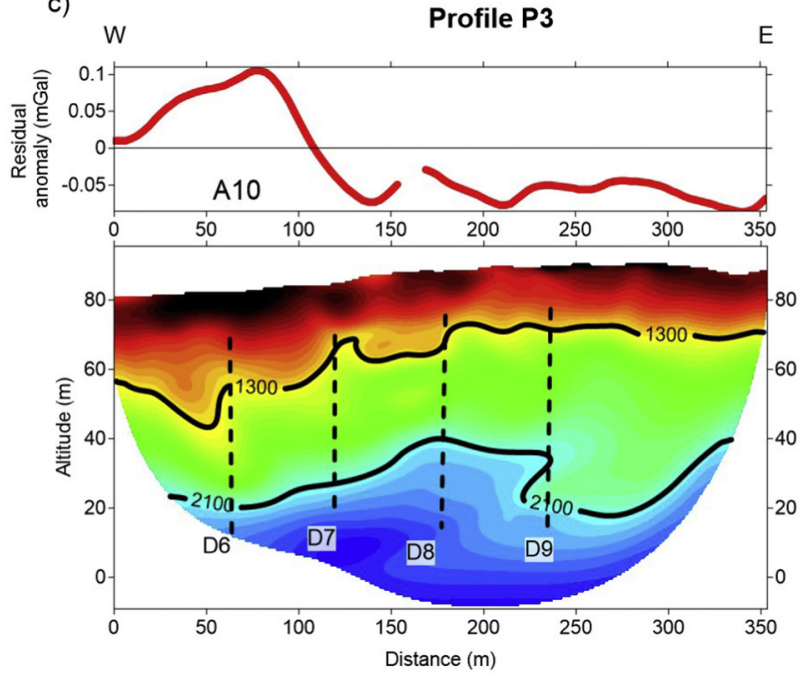

$\mathrm{Vp}(\mathrm{m} / \mathrm{s})$

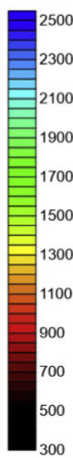

b)

E W
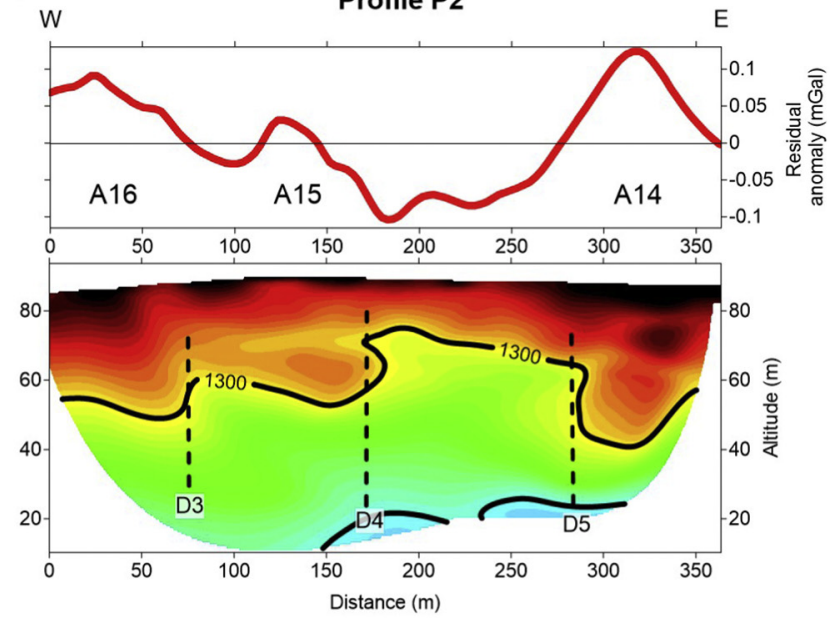

d)
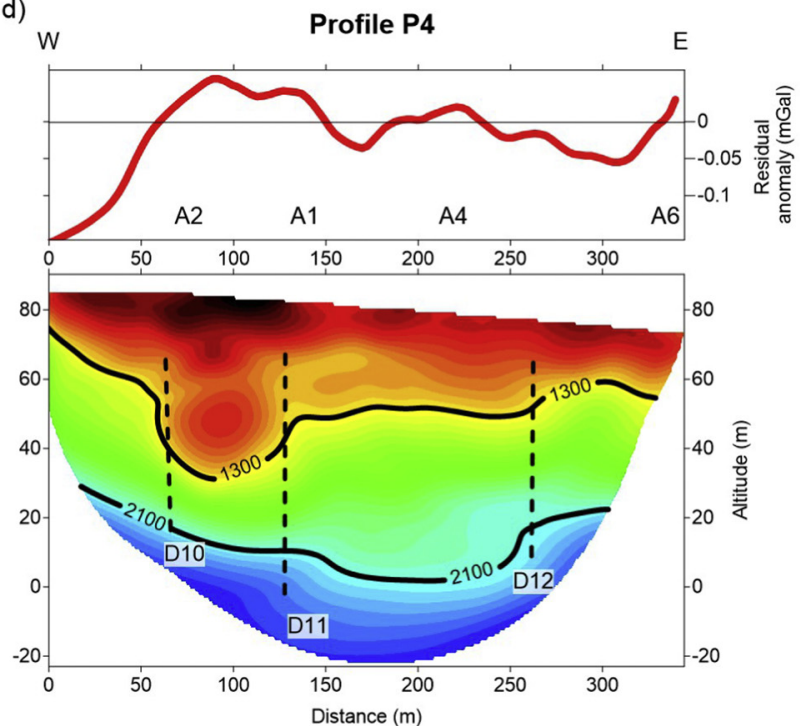

e)

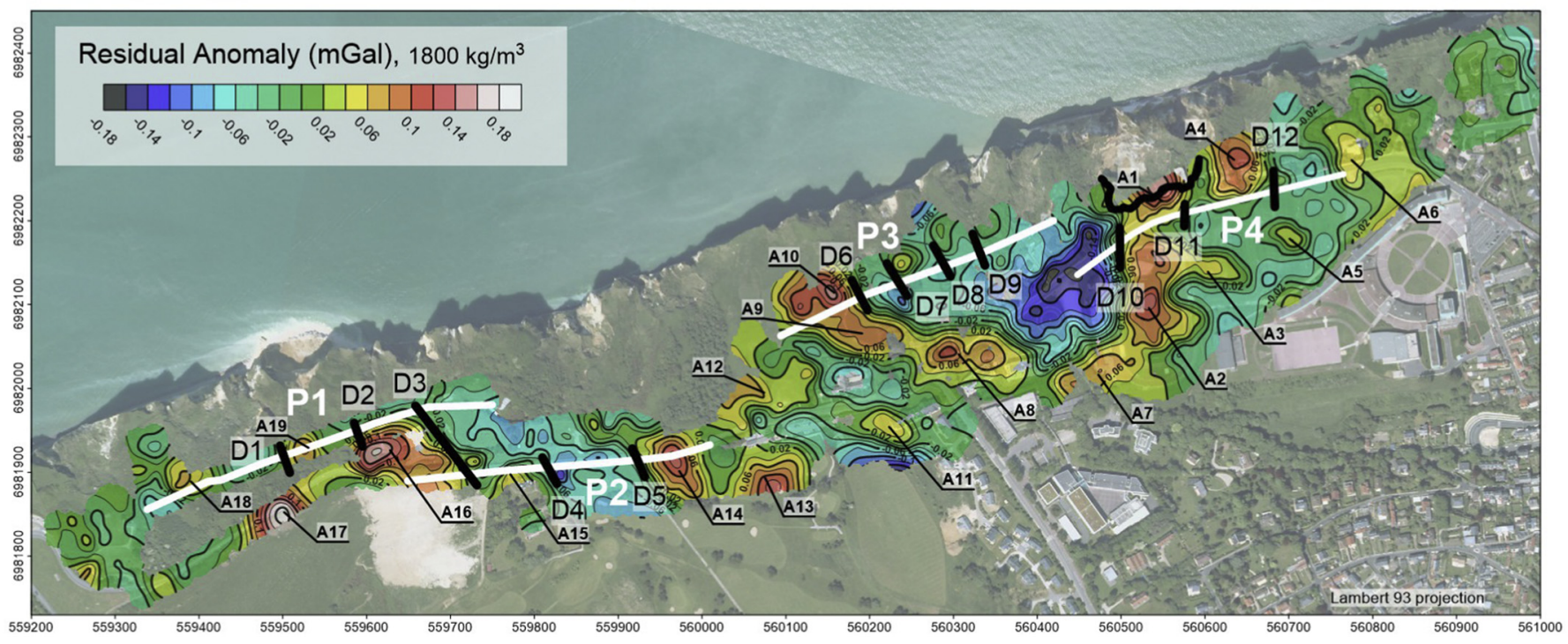

Fig. 10. Gravity residuals and seismic tomography P-wave velocity cross sections for a) profile P1, b) profile P2, c) profile P3, and d) profile P4. The residual anomaly map superimposed with profile locations are shown in e). Interpreted discontinuities are labelled D1 to D12 and are represented as dashed lines on the seismic cross sections, and as black lines on the gravity residual map. 


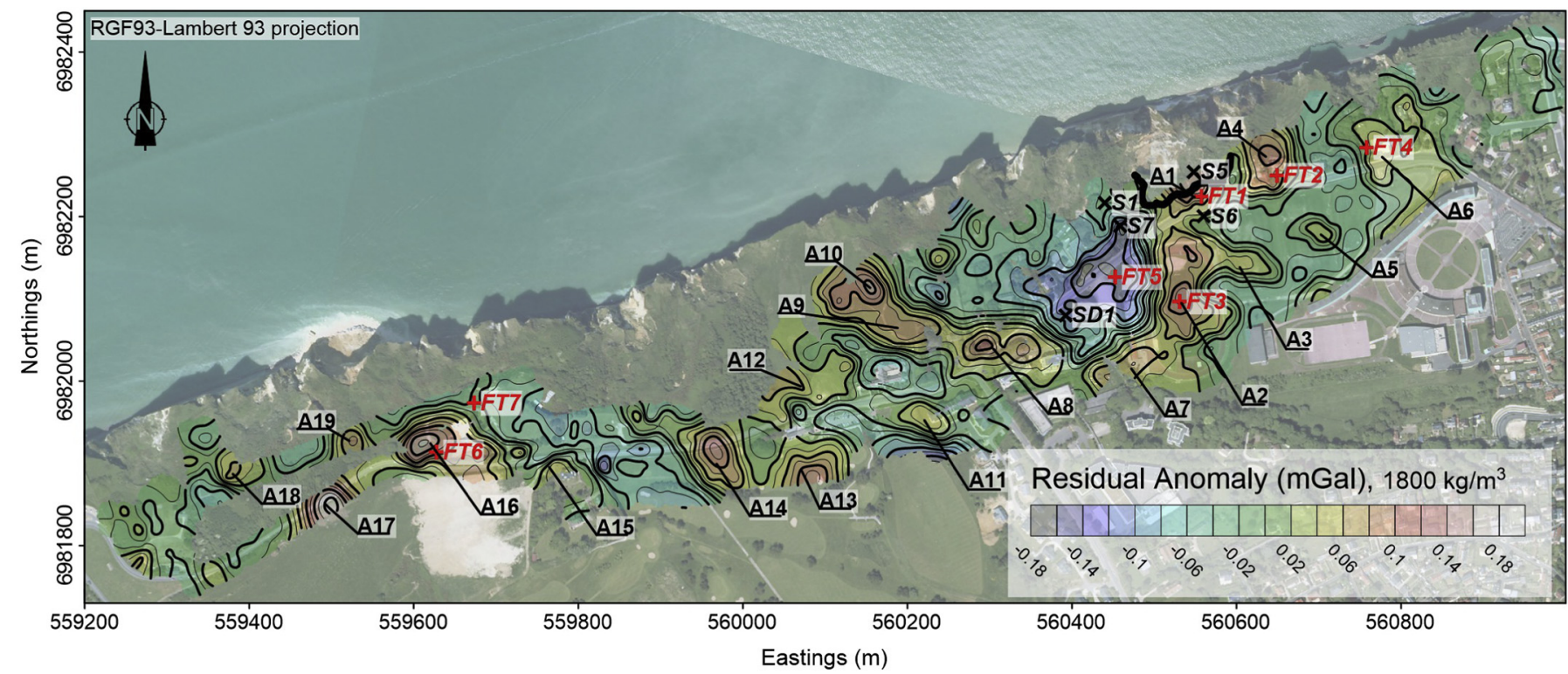

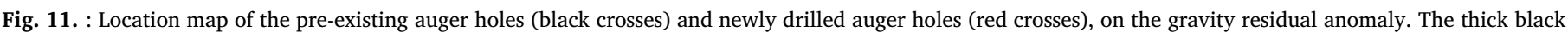

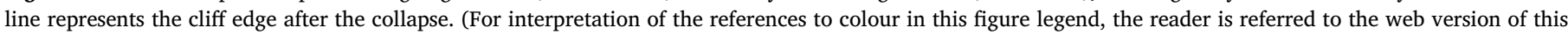
article.)

based on the method described by Bott (1960), and recently refined by Silva et al. (2014). To accommodate the fact that the density contrast between the chalk and detrital sediments is unknown, different density contrasts were tested, ranging between $200 \mathrm{~kg} / \mathrm{m}^{3}$ and $500 \mathrm{~kg} / \mathrm{m}^{3}$, using a step of $50 \mathrm{~kg} / \mathrm{m}^{3}$. A positive density contrast lead to a strictly positive gravity signal from our inverted models, whereas the observed gravity residuals span $-0.180 \mathrm{mGal}$ to $0.180 \mathrm{mGal}$ (Fig. 7). Therefore, for each tested density contrast, the input for the inversion consisted in the residual gravity anomaly shifted by a constant. This constant is defined so that the resulting mean residual value at boreholes and auger holes located within the negative anomalies, S1, S7, SD1, FT5 and FT7, corresponds to the attraction of a Bouguer slab having the depth of the chalk at these boreholes, with the prescribed density contrast. This way, the model gravity and the residual gravity correspond where the chalk's depth is known. The chalk's depth in newly drilled auger holes within positive anomalies was not included in the evaluation of this constant because the Bouguer slab approximation is not appropriate in regions exhibiting important depth variability, as is expected in or near the positive gravity anomalies. The iterative procedure was stopped when the root mean square error between modeled and measured gravity was smaller than the measurement error, here $0.012 \mathrm{mGal}$. Topography was taken into account using the $5 \mathrm{~m}$ down-sampled LIDAR DEM.

For each density contrast, we compare inverted depths to the inverted P-wave velocity cross-sections (Fig. 13) and to the depth of the chalk from the available boreholes and auger holes.

The chosen density contrast, which leads to a chalk's depth that both

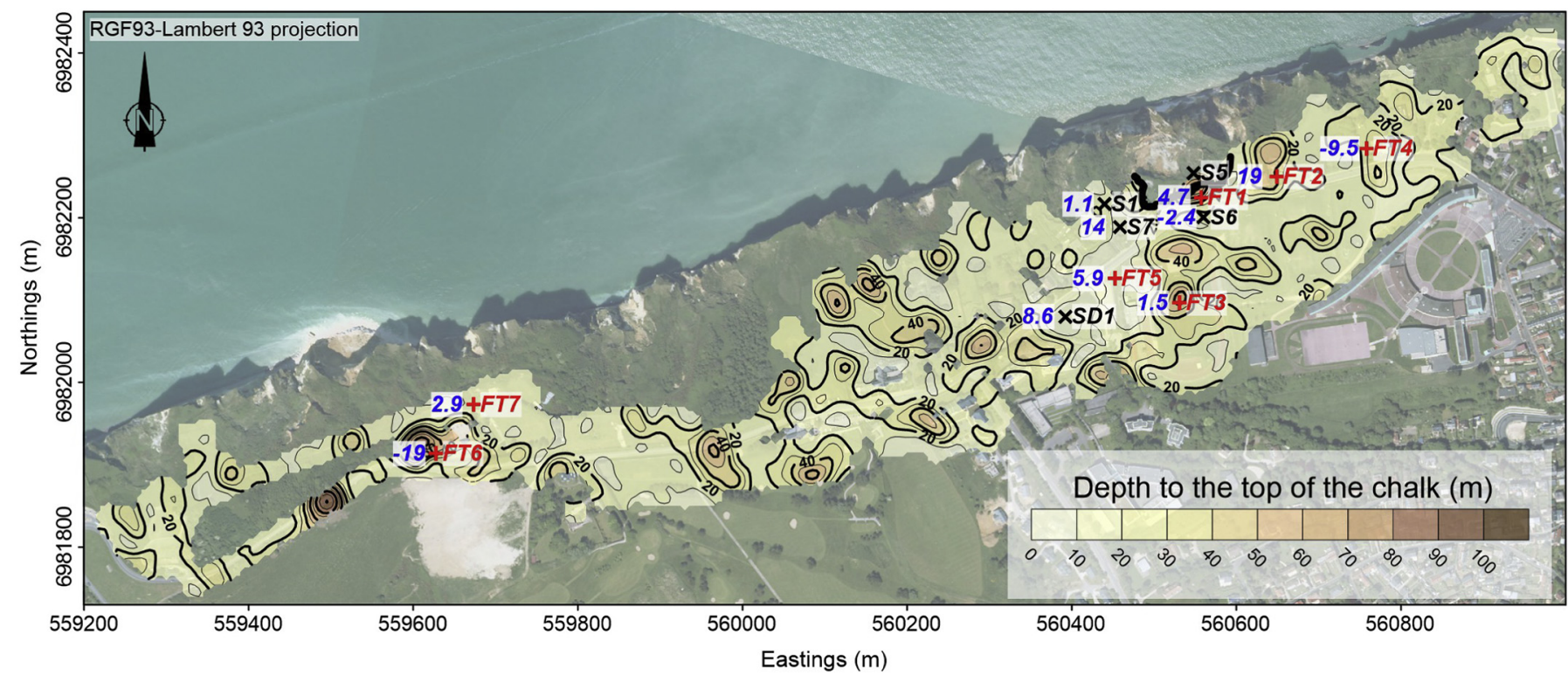

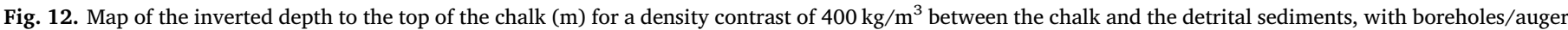

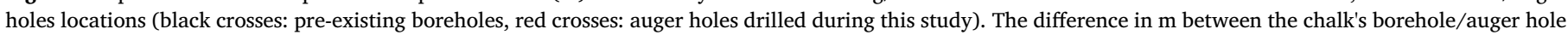

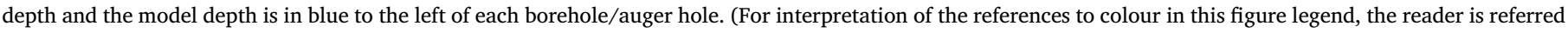
to the web version of this article.) 
a)

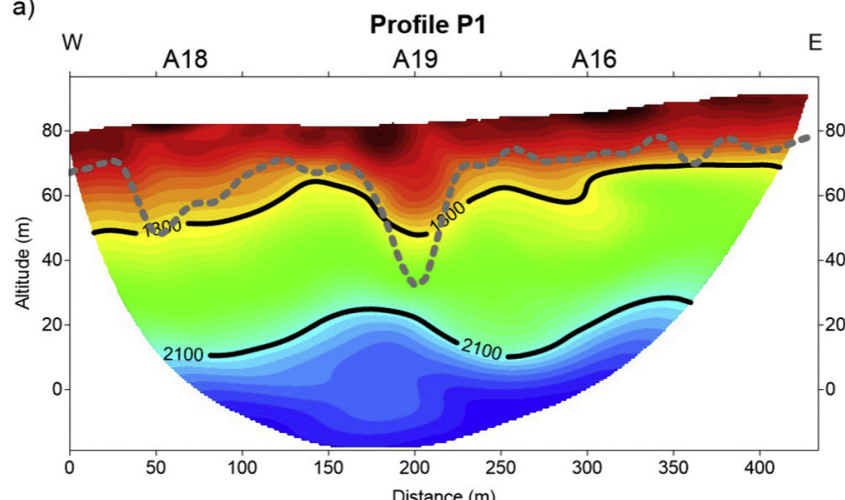

c)

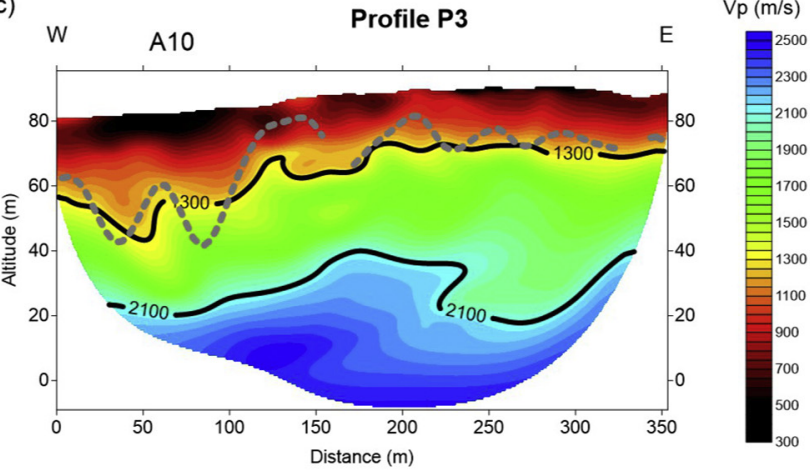

b)

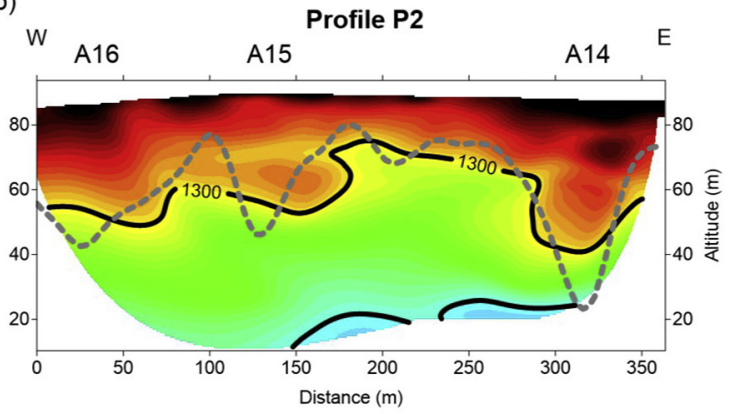

d)

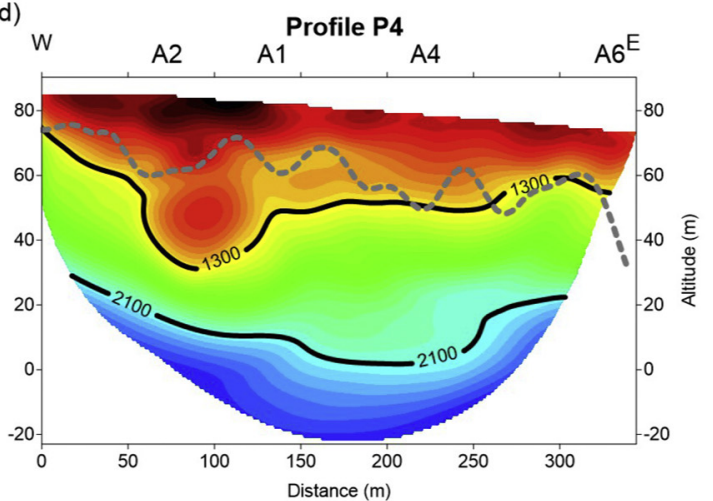

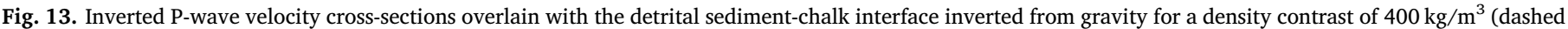
grey line), for a: profile $\mathrm{P} 1$, b: profile $\mathrm{P} 2$, c: profile $\mathrm{P} 3$ and d: profile $\mathrm{P} 4$.

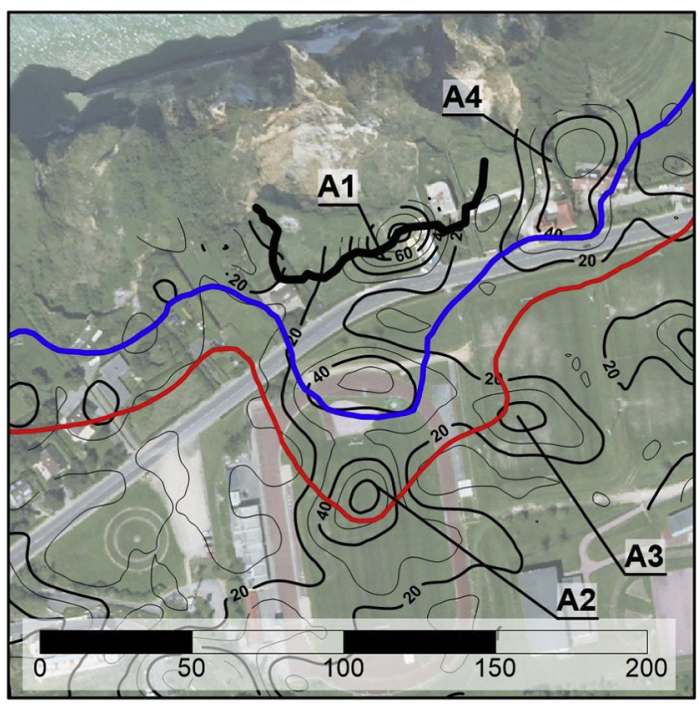

Fig. 14. Coastal landslide hazard zonation for a 10-year assessment period (blue line) and a 100-year assessment period (red line), around the active landslide. Contour lines are the depth of the chalk's top in $\mathrm{m}$ inverted from gravity. The thick black line represents the cliff edge after the collapse. (For interpretation of the references to colour in this figure legend, the reader is referred to the web version of this article.)

compares favourably to that measured in boreholes and auger holes and the seismic tomography first horizon, is $400 \mathrm{~kg} / \mathrm{m}^{3}$ (Fig. 12). Using this density contrast, the difference in chalk's depth between that in the available boreholes and that from the model is at most $19 \mathrm{~m}$ in magnitude, for auger holes FT2 and FT6. Over the entire boreholes/auger holes dataset, the mean difference is $2.5 \mathrm{~m}$, with a standard deviation of $10.4 \mathrm{~m}$.
Table 3

Newly drilled boreholes characteristics.

\begin{tabular}{|c|c|c|c|}
\hline Auger hole & $\begin{array}{l}\text { Depth of the top } \\
\text { of the Chalk (m) }\end{array}$ & Geophysical rationale & Risk assessment \\
\hline FT1 & $>55 \mathrm{~m}$ & $\begin{array}{l}\text { Anomaly A1, low } \\
\text { seismic velocity zone }\end{array}$ & $\begin{array}{l}\text { Between cliff edge } \\
\text { and major road }\end{array}$ \\
\hline FT2 & 58 & Anomaly A4 & Private house \\
\hline FT3 & 63 & Anomaly A2 & Sports stadium \\
\hline FT4 & 20 & Anomaly A6 & Private house \\
\hline FT5 & 12 & Negative anomaly & calibration \\
\hline FT6 & 27 & Anomaly A16 & $\begin{array}{l}\text { Between cliff edge } \\
\text { and major road }\end{array}$ \\
\hline FT7 & 19 & Negative anomaly & Calibration \\
\hline
\end{tabular}

The model predicts the chalk's depth at $61.7 \mathrm{~m}$ at auger hole FT1, which is in agreement with the fact that the chalk was not reached there at $55 \mathrm{~m}$ depth, and only $4.7 \mathrm{~m}$ deeper than the estimated depth of $57 \mathrm{~m}$ (Table 3). Likewise, the model predicts a chalk's depth at $64.5 \mathrm{~m}$ for auger hole FT3, which is very close to the measured depth of $63 \mathrm{~m}$ there.

The inverted depth interface from gravity does not strictly follow a single P-Wave isocontour (Fig. 13), yet it shows clear correlation with the general trend in the deepening or in the rise of the $\mathrm{Vp}$ isocontours. Indeed, good correlation is observed between the first seismic layer $(\mathrm{Vp}<1300 \mathrm{~m} / \mathrm{s}$ ) and the gravity derived depth of the chalk. One notable exception is observed in profile P4, near the cliff collapse (abscissa 70-120 m, Fig. 13d). In this region, seismic tomography predicts the top of the chalk reached at its deepest $31 \mathrm{~m}$ a.s.l., whereas the gravity-derived top of the chalk is reached at its deepest $60 \mathrm{~m}$ a.s.l. This discrepancy is further discussed in the discussion section.

The map of the detrital cover's thickness mimics that of the residual anomalies (compare Fig. 7 and Fig. 12): positive gravity anomalies lead to the inversion of important thicknesses in the detrital cover, as the 
chalk-sediment density contrast is positive. Inverted depths delineate distinct oval-shaped depressions incised within the top of the chalk and aligned in the N110 direction. These depressions are typically 40 to $60 \mathrm{~m}$ deep. The two deepest depressions are located in the western part of the study area, having depths larger than $80 \mathrm{~m}$, and correspond to anomalies A16 and A17 (Fig. 7). Nevertheless, because the gravity coverage is scarce in this region, the inverted depths are poorly constrained and are likely biased.

\section{Discussion}

\subsection{Geophysical results}

In the vicinity of the cliff collapse (abscissa $70-120 \mathrm{~m}$ of P4, Fig. 13d), gravity and seismic tomography show a discrepancy on the elevation of the chalk's top.

To explain this discrepancy, we invoke a side-lobe perturbation effect in the seismic wavepath. Most of the studies on horizontal resolution focus on the measurement of wavelet widths for seismic wavepaths, but neglect to evaluate the effect of side-lobe perturbations on spatial resolution. The side-lobe effect is important for seismic velocity reconstruction in complex media. In complex media with such steep structures and discontinuity zones, the propagation effect of seismic wave fields caused by lateral variations in velocity on structural imaging further reduces the peak-to-side lobe ratio of spatial resolution by increasing the variance (Berkhout, 1984).

Considering the abrupt lateral changes seen in the depth to the chalk's top (Fig. 12), it is likely that the relatively low frequency $(\sim 25 \mathrm{~Hz})$ seismic wave field undergoes lateral influences as it propagates in the vicinity of some major depressions. This effect may be particularly strong along abscissa $70-120 \mathrm{~m}$ of profile $\mathrm{P} 4$, where deep depressions lie in direct vicinity to and on both sides of the profile (Fig. 12). This may generate an overestimation of the elevation of the chalk's top by seismic tomography. The main velocity anomaly identified on the profile P4 may have an overestimated depth. It is not possible to account quantitatively for the influence of macroscopic anisotropy. Nevertheless, the general distribution of anomalously low velocities highlighted in Figs. 8, 9 and 13 is likely to be a reasonable first-order approximation to the actual situation in the subsurface.

The gravity-based inversion of the chalk's top is a first order approximation, relying upon simplifying assumptions, which may not be tenable. Indeed, we consider a laterally homogeneous, two layers density model. Examination of the inverted P-wave cross sections and the drilled auger hole logs reveal that the detrital material is extremely heterogeneous both with depth and laterally. This leads to lateral and depth variability in density, which our modeling cannot account for. Furthermore, the chalk bedrock is also heterogeneous, exhibiting a weathered layer of variable thickness. Hence, the inverted depths from gravity represent a first order approximation, and they do not account for, and are influenced by, the seemingly complex density structure of the detrital cover and the chalk bedrock. Such a map is however useful to assess the hazard.

From the modeling results, the optimal density contrast between the uppermost sand and clay layer and the chalk layer, is $400 \mathrm{~kg} / \mathrm{m}^{3}$. Considering a chalk density of $1800 \mathrm{~kg} / \mathrm{m}^{3}$, as measured in the study area (Duperret et al., 2005), this leads to a sand and clay unit mean density of $2200 \mathrm{~kg} / \mathrm{m}^{3}$. This density is consistent with the range given by Nettleton (1971).

\subsection{Geological interpretation}

It is not within the scope of this article to precisely assess the nature, age and origin of the sand and clay filled depressions evidenced in this study. However, we formulate a first-hand interpretation: these depressions in the top of the chalk could be of karstic nature, and represent large swallow holes or sinkholes. The Upper Cretaceous chalk in
Normandy contains both geomorphologic and hydrologic features of karstic origin (Massei et al., 2003; Rodet, 1999; Valdes et al., 2007), it is therefore reasonable to invoke karst processes in this context. The absence of clay-with-flints within these depressions is peculiar, as claywith-flints are predominantly present above the chalk in this region, and commonly fill karstic features (Quesnel, 1997; Quesnel et al., 2003).

To explain this observation, we hypothesize that those karstic features may have been used by running waters, thereby eroding any preexisting clay-with-flints and depositing the fluvial sediments. The depressions may even have been hydrologically connected, forming paleovalleys.

We also surmise that these depressions developed after the deposit of the Paleogene Formations, during an interval of strong incision. Their location seems controlled by pre-existing faults or discontinuities within the chalk. The dominant fault system, as observed on the cliff faces of the study area (Pannet et al., 2015), has a $\mathrm{N} 110^{\circ}$ to $\mathrm{N} 120^{\circ}$ azimut and a sub vertical dip, but the vertical offset of the chalk and flint beds is very small and in most cases even negligible. This orientation compares favourably with the direction of observed aligned depressions, as inverted from gravity (Fig. 12) and as seen on the residual anomaly map (Fig. 7).

The depressions/paleovalleys were later filled by fluvial deposits, as evidenced by the gravelly, sandy and clayey facies and by the identified distinct fining-upwards sequences in the auger holes. Those detrital sediments may originate from the surrounding reworked Paleogene sandy and clayey sediments and the flint gravels may come from the Paleogene flint gravels and more probably from the eroded chalk's flint beds, yet this needs to be corroborated by further studies, which could also allow dating these fluvial sediments.

Finally, to our knowledge, this is the first study that precisely locates and assesses the geometry and the infilling of deep depressions in chalk cliff coastal regions. Similar depressions in chalk clifftops may well exist elsewhere around the English Channel, yet one needs to first understand their origin and context of formation in order to locate other possible affected zones.

\subsection{Outcome of the study}

The successful mapping of the previously poorly documented sand and clay-filled depressions on the Dieppe clifftop, using both gravity and seismic refraction tomography, was used as input to generate a coastal landslide hazard zonation (CLHZ) map (Jongens et al., 2007; Moon and Healy, 1994) for managers who need to make hazard-mitigating decisions to preserve human life.

The sand and clay-filled depression are considered a hazard if they are close to the cliff-line, where failure of the chalk cliff-face is bound to happen. In this case, the rate of retreat of the clifftop affecting the sand and clay-filled depressions is some orders of magnitude higher that that affecting the chalk cliff, as the involved physical processes differ. The sand and clay material will tend to creep down to the tidal flat, and the phenomena will not stop until the angle of repose is reached. Therefore, detailed knowledge on the location and geometry of these sedimentfilled depressions, as brought forth by geophysical investigations and verified by auger holes, is a key parameter to define a hazard zonation map.

The CLHZ map was generated using (i) the rate of long-term sea-cliff retreat; (ii) the amount of horizontal retreat expected from identified cliff-failure mechanisms including joint block fall and fault plane failure, (iii) the amount of horizontal retreat resulting from slumping of the top Paleogene formations, (iv) the amount of horizontal retreat resulting from slumping and emptying of the sand and clay filled depressions and ( $\mathrm{v}$ ) a safety factor.

It is outside the scope of the present paper to precisely describe the methodology used to generate this hazard zonation map, the methodology is described in Pannet et al. (2015). The coastal landslide hazard 
zonation was assessed for a 10-year period and a 100-year period (Fig. 14).

Based on the CLHZ map (Pannet et al., 2015), coastal managers decided to close and relocate infrastructure located immediately to the South of the landslide (Fig. 14). A section of the road from Dieppe to Pourville-sur-Mer and the sports facilities including the $400 \mathrm{~m}$ track and rugby fields are being relocated at the time of writing this article. These facilities are indeed located within the 10-year hazard zone, whose shape is largely influenced by the presence of a sand and clay-filled depressions identified in this study, corresponding to the northern part of anomaly A2. A private house, located on the sand-and-clay filled depression corresponding to anomaly A4, and within the 10-year hazard zone, was also expropriated. Over the rest of the study area, no other facility was located within the 10-year hazard zone.

\section{Conclusions}

In this paper, we describe a complete and successful case history wherein gravity and seismic refraction prospecting detect and map previously poorly known sand and clay-filled depressions affecting the top of the chalk in a costal context, near Dieppe, Normandy, France. This study was commissioned by local authorities after that a cliff collapse turned into a massive landslide, exposing a previously poorly known sand and clay-filled depression within the clifftop.

Using information from pre-existing boreholes on the site, we associate the $1300 \mathrm{~m} / \mathrm{s}$ seismic P-wave velocity with the horizon of clay and sand units on top of the chalk. Localized depressions within this uppermost horizon are observed within the inverted seismic cross-sections, which we interpret as the sand-and-clay filled depressions.

The gravity residual anomaly map shows elongated string-like positive anomalies, which we interpret as the signal resulting from these depressions, since we argue that the sand and clay units are denser than the chalk beneath.

Joint interpretation of the gravity and seismic results confirm and strengthen the interpretation of each method taken individually: good correlation is observed between the positive gravity anomalies and local deepening of the $1300 \mathrm{~m} / \mathrm{s}$ P-wave velocity contour.

Five auger holes were drilled within the identified geophysical anomalies and confirm our interpretations: depths to the top of the chalk larger than $50 \mathrm{~m}$ are found within some positive gravity anomalies. Identified sediments in the boreholes are structured in fluvial fining-upward sequences, from gravel to sand and clay and do not correspond to the known Paleogene Formations present in the area on top of the chalk, which they also crosscut. Two auger holes drilled in negative gravity anomalies confirm the presence of $<20 \mathrm{~m}$ of the expected Paleogene Formations.

Using a two-layer model, we invert a map of the chalk's top from the gravity data and find that a density contrast of $400 \mathrm{~kg} / \mathrm{m}^{3}$ between the sand and clay units and the chalk compares favourably to the seismic profiles and to the known depth of the chalk in the boreholes/auger holes. The inverted map highlights a string of localized depressions, some $40 \mathrm{~m}$ to $60 \mathrm{~m}$ deep, having orientations comparable to that of the known discontinuities on site. Based in part on the findings of this study, a hazard zonation map was created, which led local coastal managers to close and relocate infrastructures built on top of the identified depressions, near the landslide.

We now need to understand the origin of these depressions, in order to assess if they might be present in other coastal regions along the English Channel. If such is the case, the methodology applied in this paper will prove useful to map their extent and depths, for hazard assessment and mitigation.

Furthermore, the geophysical methodology applied in this study may be used to detect map vertical dissolution pipes occurring within the chalk, which have been shown to be problematic during construction work of roads in the Brighton region, Britain (Mortimore, 2012).

\section{Acknowledgements}

This study was jointly funded by the 'Direction Départementale des Territoires et de la Mer de la Seine-Maritime' and by BRGM, under project PSP14HNO10.

Some of the writing time for this paper was supported by the ANR project RICOCHET: multi-RIsk assessment on Coastal territory in a global CHange context funded by the French Research National Agency (ANR-16-03-0008CE).

We are indebted to M. Boulet, R. Barbier, L. Raymond, L. Ardito, G. Guizouarn and B. François for their precious help in the field during the geophysical and auger hole drilling campaigns.

\section{References}

Ahmed, S., Carpenter, P.J., 2003. Geophysical response of filled sinkholes, soil pipes and associated bedrock fractures in thinly mantled karst, east-central Illinois. Environ. Geol. 44 (6), 705-716.

Amante, C., Eakins, B.W., 2009. ETOPO1 1 arc-minute global relief model: procedures, data sources and analysis. US Department of Commerce, National Oceanic and Atmospheric Administration, National Environmental Satellite, Data, and Information Service. National Geophysical Data Center, NOAA. Mar. Geol. Geophy. Div. https://doi.org/10.7289/V5C8276M. (accessed 4 April 2018).

Berkhout, A.J., 1984. Seismic Resolution: A Quantitative Analysis of Resolving Power of Acoustical Echo Techniques. Geophysical Press, pp. 12.

Bignot, G., 1971. Carte Géologique de la France à 1/50000, feuille de Dieppe Ouest $\left(n^{\circ} 42\right)$. (Ed. BRGM).

Bos, M.S., Scherneck, H.G., 2007. Free Ocean Tide Loading Provider. http://holt.oso. chalmers.se/loading/index.html.

Bott, M.H.P., 1960. The use of rapid digital computing methods for direct gravity interpretation of sedimentary basins. Geophys. J. Int. 3 (1), 63-67.

Bourbié, T., Coussy, O., Zinszner, B., 1987. Acoustics of Porous Media: Editions Technip. (Paris, France).

Clarke, S., 2015. Tour de France 2015 route revised following landslide. http://www. cyclingweekly.com/news/racing/tour-de-france/tour-de-france-2015-route-revisedfollowing-landslide-149029\#6EJVkDZd0v12DOgl.99In: Cycling Weekly, (accessed 4 April 2018).

D'Errico, J., 2005. Surface Fitting Using Gridfit. MATLAB Central File Exchange.

Dehant, V., Defraigne, P., Wahr, J.M., 1999. Tides for a convective Earth. J. Geophy. Res. 104 (B1), 1035-1058.

Dewez, T., 2014. Reconstructing 3D coastal cliffs from airborne oblique photographs without ground control points. ISPRS Annals of the Photogrammetry. Remote Sens. Spat. Inf. Sci. 2 (5), 1.

Dobrin, M.B., Savit, C.H., 1960. Introduction to Geophysical Prospecting, 4. McGraw-hill, New York

Dugué, O., Bourdillon, C., Quesnel, F., Lautridou, J.-P., 2012. The neogene and lower Pleistocene crags of Upper Normandy: Biostratigraphic revision and paleogeographic implications. Compt. Rendus Geosci. 344 (8), 415-422.

Duperret, A., Genter, A., Martinez, A., Mortimore, R.N., 2004. Coastal chalk cliff instability in NW France: role of lithology, fracture pattern and rainfall. Eng. Geol. Spec. Publ. 33-56.

Duperret, A., Taibi, S., Mortimore, R.N., Daigneault, M., 2005. Effect of groundwater and sea weathering cycles on the strength of chalk rock from unstable coastal cliffs of NW France. Eng. Geol. 78 (3), 321-343.

Dupuis, C., Steurbaut, E., 1987. Altérites, sables marins (NP8, NP9) et fluviatiles, silicification et stromatolites dans le Paléocène supérieur entre Criel et le Cap d'Ailly (Haute Normandie). Annales de la Société Géologique du Nord 105, 233-242.

Dupuis, C., Steurbaut, E., De Coninck, J., Riveline, J., 1998. The Western Argiles à lignite facies. Cap-d'Ailly sections. Mémoires des Sciences de la Terre/Ecole des Mines de Paris 34, 60-71.

Garel, S., Schnyder, J., Jacob, J., Dupuis, C., Boussafir, M., Le Milbeau, C., Storme, J.-Y., Iakovleva, A.I., Yans, J., Baudin, F., Fléhoc, C., Quesnel, F., 2013. Paleohydrological and paleoenvironmental changes recorded in terrestrial sediments of the PaleoceneEocene boundary (Normandy, France). Palaeogeogr. Palaeoclimatol. Palaeoecol. 376, 184-199.

Jongens, R., Gibb, J., Alloway, B.V., 2007. A new hazard zonation methodology applied to residentially developed sea-cliffs with very low erosion rates, East Coast Bays, Auckland, New Zealand. Nat. Hazards 40 (1), 223-244.

Lyard, F., Lefevre, F., Letellier, T., Francis, O., 2006. Modelling the global ocean tides: modern insights from FES2004. Ocean Dyn. 56 (5-6), 394-415.

Massei, N., Wang, H.Q., Dupont, J.P., Rodet, J., Laignel, B., 2003. Assessment of direct transfer and resuspension of particles during turbid floods at a karstic spring. J. Hydrol. 275 (1-2), 109-121.

Masson, M., 1967. Effondrement de terrains côte ouest de Dieppe, rapport 3426, Organisme Technique Régional des Ponts et Chaussées.

Moon, V.G., Healy, T., 1994. Mechanisms of coastal cliff retreat and hazard zone delineation in soft flysch deposits. J. Coast. Res. 663-680.

Moritz, H., 1980. Geodetic reference system 1980. J. Geod. 54 (3), 395-405.

Mortimore, R.N., 2012. Making sense of Chalk: a total-rock approach to its Engineering Geology. Q. J. Eng. Geol. Hydrogeol. 45 (3), 252-334.

Mortimore, R.N., Lawrence, J., Pope, A., Duperret, A., Genter, A., 2004. Coastal cliff 
geohazards in weak rock; the UK chalk cliffs of Sussex. Eng. Geol. Spec. Publ. 3-31. Nagy, D., Papp, G., Benedek, J., 2000. The gravitational potential and its derivatives for the prism. J. Geod. 74 (7-8), 552-560.

Nettleton, L.L., 1971. Gravity and Magnetics for Geologists and Seismologists. SEG Books. Pannet, P., Meire, B., Boulet, M., Quesnel, F., Jacob, T., Samyn, K., Bitri, A., Dewez, T.,

2015. Détermination de l'aléa recul de la falaise. Application à la région dieppoise. (Rapport final. BRGM/RP-65008-FR).

Parasnis, D.S., 1952. A study of rock densities in the English Midlands. Geophy. Suppl. Mon. Not. R. Astron. Soc. 6 (5), 252-271.

Quesnel, F., 1997. Cartographie numérique en géologie de surface - Application aux altérites à silex de l'ouest du Bassin de Paris (PhD Thesis). 268 Université de Rouen.

Quesnel, F., Catt, J., Laignel, B., Bourdillon, C., Meyer, R., 2003. The Neogene and Quaternary Clay-with-flints north and south of the English Channel: comparisons of distribution, age, genetic processes and geodynamics. J. Quat. Sci. 18 (3-4), 283-294.

Rao, V.B., Murty, B.V.S., 1973. Note on Parasnis' method for surface rock densities. Pure Appl. Geophys. 110 (1), 1927-1931.

Rodet, J.1., 1999. Tectonic network as the initial factor of karstification of the chalk limestones in the Perche hills (Orne, Normandy, France). Geodin. Acta 12 (3), 259-265.
Schiavone, D., Capolongo, D., Loddo, M., 2009. Near station topographic masses correction for high-accuracy gravimetric prospecting. Geophys. Prospect. 57 (4), 739-752.

Schuster, G.T., Quintus-Bosz, A., 1993. Wavepath eikonal traveltime inversion: theory Geophysics 58 (9), 1314-1323.

Senfaute, G., Amitrano, D., Lenhard, F., Morel, J., Gourry, J.C., 2005. Etude experimentale en laboratoire de l'endommagement des roches de craie par methode acoustique et correlation avec des resultats in-situ. Rev. Fr. Géotech. 110, 9-18.

Sheehan, J.R., Doll, W.E., Mandell, W.A., 2005. An evaluation of methods and available software for seismic refraction tomography analysis. J. Environ. Eng. Geophys. 10 (1), 21-34.

Silva, J.B.C., Santos, D.a.F., Gomes, K.P., 2014. Fast gravity inversion of basement relief. Geophysics 79 (5), G79-G91.

Valdes, D., Dupont, J.-P., Laignel, B., Ogier, S., Leboulanger, T., Mahler, B.J., 2007. A spatial analysis of structural controls on Karst groundwater geochemistry at a regional scale. J. Hydrol. 340 (3-4), 244-255.

Zhou, W., Beck, B.F., Stephenson, J.B., 2000. Reliability of dipole-dipole electrical resistivity tomography for defining depth to bedrock in covered karst terranes. Environ. Geol. 39 (7), 760-766. 